\title{
Dilemmas of Poland's foreign and security policies in the post-Cold War period in the context of its geopolitical location between Russia and Germany
}

\section{Dylematy polityki zagranicznej i bezpieczeństwa Polski w okresie pozimnowojennym w kontekście jej geopolitycznego usytuowania między Rosją a Niemcami}

\author{
Mieczysław Stolarczyk*
}

\begin{abstract}
The research objective of this paper is the presentation of the influence (significance) of the geopolitical factor in Poland's relations with the Russian Federation (Russia) and the Federal Republic of Germany (Germany) in the post-Cold War period, first and foremost the influence on the shares of convergent and divergent (contradictory) interests of Poland and the two countries, as well as relevant dilemmas concerning Poland's foreign and security policies. The main research thesis is that the geopolitical factor remains one
\end{abstract}

\begin{abstract}
Abstrakt
Celem badawczym w artykule jest ukazanie wpływu (znaczenia) czynnika geopolitycznego w stosunkach Polski z Federacją Rosyjską (Rosją) i Republiką Federalną Niemiec (Niemcami) w okresie pozimnowojennym, w tym przede wszystkim na stopień zbieżnych i rozbieżnych (sprzecznych) interesów z tymi państwami oraz na dylematy z tym związane dla polityki zagranicznej i bezpieczeństwa Polski. Główna teza badawcza zawiera się $\mathrm{w}$ stwierdzeniu, że czynnik geopolityczny, mimo zmian zachodzących $\mathrm{w}$ ostatnich dziesię-
\end{abstract}

* Institute of Political Science, Faculty of Social Sciences, University of Silesia in Katowice; (e-mail: meczyslaw.stolarczyk@us.edu.pl) :iD hetps://orcid.org/0000-0002-9771-0062. 
of the chief determinants of Poland's relations with Russia and Germany despite the changes taking place in the international system (e.g. the acceleration of globalisation processes) in the last few decades. In the post-Cold War period, however, it affected Poland's relations with Russia in a much more negative way than it did the Polish-German relations. The German problem in its traditional sense of a hazard source diminished considerably in the Polish foreign policy in the abovementioned period, while the significance of the Russian problem increased. The decision makers of the Polish foreign policy viewed Germany first and foremost as a partner and an ally (within NATO), while Russia was seen as the main hazard to Polish security, including a military hazard in the form of a direct invasion.

Wishing to present more detailed matters, the paper brings to the fore i.a. the issues concerning the essence of the geopolitical factor in the foreign policies of countries, certain conditions of Poland's geopolitical location in the post-Cold War period, the main stages of Poland's relations with Germany and Russia in that period together with their characteristics, the main areas of divergent interests in Poland's relations with Germany and Russia in the second decade of the 21 st century, the similarities and differences in Poland's policy toward Germany and Russia in the post-Cold War period as well as the main dilemmas of the Polish foreign policy toward the end of the second decade of the 21st century stemming from Poland's geopolitical location between Russia and Germany.

One main conclusion formulated on the basis on those deliberations is that Poland's geopolitical location between Russia and Germany does not doom Polish relations with the two countries to a confrontational nature for historical reasons. The geopolitical factor is not an independent prime mover; it does not entail geopolitical determinism which automatically eliminates the possibility of influencing Poland's geopolitical situation by subsequent Polish gov- cioleciach w systemie międzynarodowym (np. przyspieszenie procesów globalizacji), jest nadal jedną $\mathrm{z}$ głównych determinant stosunków Polski z Rosją i Niemcami. Jednakże w okresie pozimnowojennym rzutował on zdecydowanie bardziej negatywnie na stosunki Polski z Rosją niż na relacje Polski z Niemcami. W omawianym okresie w polityce zagranicznej Polski znacznie zmalało znaczenie problemu niemieckiego, w jego tradycyjnym rozumieniu źródeł zagrożenia, rosło natomiast znaczenie problemu rosyjskiego. Niemcy były postrzegane przez decydentów polskiej polityki zagranicznej przede wszystkim jako partner i sojusznik (w ramach NATO), natomiast Rosja, jako główne zagrożenie dla bezpieczeństwa Polski, w tym także jako zagrożenie militarne (zagrożenie bezpośrednią napaścią zbrojną).

Mając na uwadze zagadnienia bardziej szczegółowe, w opracowaniu wyeksponowane zostały m.in. kwestie dotyczące istoty czynnika geopolitycznego $\mathrm{w}$ polityce zagranicznej państw, niektóre uwarunkowania geopolitycznego usytuowania Polski w okresie pozimnowojennym, główne etapy i ich cechy charakterystyczne w stosunkach Polski z Niemcami i Rosją w tym czasie, główne obszary rozbieżnych interesów w stosunkach Polski z Niemcami i Rosja w drugiej dekadzie XXI w., podobieństwa i różnice w polityce Polski wobec Niemiec i Rosji w okresie pozimnowojennym oraz główne dylematy polityki zagranicznej Polski pod koniec drugiej dekady XXI w. wynikające z geopolitycznego usytuowania Polski między Rosją a Niemcami.

Jeden z głównych wniosków sformułowanych na podstawie przeprowadzonych rozważań zawiera się w stwierdzeniu, że geopolityczne położenie Polski między Rosją i Niemcami nie oznacza, że mając na uwadze związane z tym zaszłości historyczne, stosunki Polski z tymi państwami skazane są na konfrontacyjny charakter. Czynnik geopolityczny nie ma bowiem charakteru samodzielnej siły sprawczej, determinizmu geopolitycznego, automatycz- 
ernments. The geopolitical location does not determine eternal enemies or eternal friends because one can derive various conceptions, programmes and objectives of the foreign policy from the same geopolitical location of Poland.

Key words: geopolitics, Poland's foreign policy, Polish-German relations, PolishRussian relations nie eliminującego możliwości wpływu kolejnych polskich rządów na zmianę geopolitycznej sytuacji Polski. Geopolityczne usytuowanie nie determinuje ani wiecznych wrogów ani wiecznych przyjaciół. $\mathrm{Z}$ tego samego położenia geopolitycznego Polski można bowiem wyprowadzić różne koncepcje, programy i cele polityki zagranicznej.

Słowa kluczowe: geopolityka, polityka zagraniczna Polski, stosunki polsko-niemieckie, stosunki polsko-rosyjskie

\section{Introduction}

When Poland regained independence in 1918, its foreign and internal policies in the subsequent periods and system forms (the Second Polish Republic, the postwar Polish republic, the Polish People's Republic and the contemporary Republic of Poland) were greatly determined by its geopolitical location between the two biggest neighbours, Germany and Russia, including by the subsequent system forms of those countries. The German system forms were: The Weimar Republic, the German Reich, the Federal Republic of Germany and the German Democratic Republic as well as reunified Germany (FRG) since 1990. The Russian system forms included: Soviet Russia, the Union of Soviet Socialist Republics (the USSR) and the Russian Federation (RF). The most important dilemma of Poland's foreign and security policies in the 20th century as well as in the first and second decade of the 21st century stems from its geopolitical location between Germany and Russia and has been included in the search for an answer to the following question: What objectives should be formulated in Poland's foreign and security policies toward those countries and what means and methods should be used to accomplish them in order to strengthen Poland's security as well as policy effectiveness in the bi- and multilateral relations with those countries? What is the convergence and divergence of interests between Poland and Germany as well as Poland and Russia in the aspects which are crucial to Poland's security? Those issues have been discussed i.a. in relevant publications penned by politicians, journalists and researchers of the Polish foreign policy. The most important works on this topic published in the first decades of the 20th century include those by Roman Dmowski and Adolf Bocheński. ${ }^{1}$

${ }^{1}$ R. Dmowski: Niemcy, Rosja i kwestia polska. Warszawa 1908; A. Bocheński: Między Niemcami a Rosja. Warszawa 1937. See more about the 19th- and 20th-century Polish geopolitical thought in: L. SyкuLSKI: Geopolityka. Skrypt dla początkujących. Częstochowa 2014, 
One must stress that the policy toward Russia and Germany as well as the relations with both countries only partially depended on Poland's actions. They were conditioned by intra-German and intra-Russian factors, the policies of those countries toward Poland, the German-Russian relations and the evolution of the global and European international system. The Polish-German relations and, even more, the Polish-Russian relations in the post-Cold war period were greatly influenced by the American factor, in particular since 1999, when Poland became a NATO Member State. The reason was that the United States played a leading role in Poland's external security policy. ${ }^{2}$ Consequently, the objectives of the USA's policy toward Russia and Germany as well as the nature of the American-German and American-Russian relations in the subsequent phases of the post-Cold war period significantly influenced Poland's policy toward Germany and Russia. It must simultaneously be highlighted that Poland's aspirations to become a NATO Member State and strengthen the bilateral relations with the USA concerning security, including i.a. the striving of Polish politicians for the elements of the American Ballistic Missile Defence (e.g. Fort Trump) to be distributed in the territory of Poland, were motivated by the sense of a hazard posed by Russia and a conviction that the United States were the only reliable guarantor of Poland's security.

Two main traditional geographic directions of the Polish foreign policy are: the Western direction and the Eastern direction. Either of them was prioritised in Poland's subsequent historical periods and social and political system forms. Referring to the two great historical ideas present in the thinking of the Polish intellectual and political elite on Poland's position in Europe, the Piast paradigm and the Jagiellonian paradigm, one can state that the entire post-Cold War period was dominated by the Piast paradigm, i.e. the priority of the Western direction in the Polish foreign policy in order to accomplish the interests stemming from Poland's reason of state as defined by the subsequent groups ruling the country after 1989.3 To Poland, its relations with the Federal Republic of Germany were the most important bilateral relations among those with European countries. After 1990, Germany was not only Poland's most important economic partner among European and non-European countries, but also its most important partner among European countries concerning politics ${ }^{4}$ and interso-

p. 95 and subs. pages; R. JuCHNOwski: Miejsce geopolityki w polskiej myśli politycznej XIX i XX wieku. Torun 2018.

2 J. Zając: Poland's Security Policy: The West, Russia, and the Changing International Order. London 2016, p. 189 and subs. pages.

${ }^{3}$ See M. Mróz: Między Polska piastowska a jagiellońską. Kontrowersje wokót kierunków polskiej polityki zagranicznej po akcesji do Unii Europejskiej. "Dyplomacja i Bezpieczeństwo" 2013, nr 1.

${ }^{4}$ One deviation from this tendency took place when Beata Szydło was the Prime Minister as representatives of her government exposed the leading role of Great Britain in this scope for a certain time. 
cial relations. However, when security (first and foremost military security) was concerned, the subsequent Polish governments ascribed the greatest importance to Poland's bilateral relations with the United States of America, especially after Poland became a NATO Member State in 1999.

The second strategic direction of the Polish foreign policy after 1989 was the Eastern (Jagiellonian) direction, which did not exclude opinions that it was actually the most important (priority) direction, with the Ukrainian vector as the crucial one. The advocates of that thinking argued that all the other directions of the Polish foreign policy (e.g. the alliance with the USA and other countries within NATO, Poland's membership in the European Union) were aimed only at building instruments to accomplish the objectives of the priority Eastern direction. ${ }^{5}$ The core of Poland's Eastern policy in the last decade of the 20th century as well as the first and second decade of the 21st century was formed by the closely connected relations with the Russian Federation (Russia) and Ukraine.

The research objective of this study is the presentation of the influence (significance) of the geopolitical factor on Poland's relations with Russia and Germany in the post-Cold War period, first and foremost the influence on the shares of convergent and divergent (contradictory) interests of Poland and the two countries, as well as relevant dilemmas concerning Poland's foreign and security policies toward the end of the second decade of the 21st century. The main research thesis is that the geopolitical factor remains one of the chief determinants of Poland's relations with Russia and Germany despite the changes taking place in the international system (e.g. the acceleration of globalisation processes) in the last few decades. In the post-Cold War period, however, it affected Poland's relations with Russia in a much more negative way than it did the Polish-German relations. The German problem in its traditional sense of a hazard source diminished considerably in the Polish foreign policy in the abovementioned period ${ }^{6}$, while the significance of the Russian problem increased. The decision makers of the Polish foreign policy viewed Germany first and foremost as a partner and an ally (within NATO), while Russia was seen as the main hazard to Polish security, including a military hazard in the form of a direct invasion. ${ }^{7}$ Though it was not highlighted in the country's official documents till 2014, the Polish elite from the Solidarność [Solidarity] movement did deem Russia the main hazard to Poland and its chief adversary already at the beginning of the 1990s. The sense

${ }^{5}$ P. Żurawski vel Grajewski: Geopolityka - siła - wola. Rzeczypospolitej zmagania z losem. Kraków 2010, p. 293-331.

${ }^{6}$ See M. Stolarczyк: Zbieżność i różnice interesów w stosunkach polsko-niemieckich $w$ latach 1989-2009. Katowice 2010.

7 See more in A. Walicki: O Rosji inaczej. Warszawa 2019; Polityka wschodnia Polskimiędzy fatalizmem geopolitycznym a klątwa niemocy. Red. S. Bieleń. Pułtusk-Warszawa 2019; M. Stolarczyк: Rosja w polityce zagranicznej Polski w latach 1992-2015. Katowice 2016. 
of a hazard posed by Germany diminished in the Polish society in the subsequent decades of the post-Cold War period, while the fear of Russia increased. That process reached its climax in 2014. The sense of a hazard posed by Russia determined Poland's foreign policy in bi- and multilateral relations, especially the policy toward the post-Soviet area, the relations with the USA, the policy in NATO and, to a large extent, the policy toward Germany and within the EU. The significance of the geopolitical factor in Poland's relations with Russia and Germany has increased in recent years due to i.a. Crimea incorporation by Russia and the conflict in eastern Ukraine as well as the growth of Germany's and Russia's superpower positions in international relations.

\section{The essence of geopolitics (the geopolitical factor) in the foreign policies of countries}

Foreign policy, including a country's security policy implemented in the external sphere, depends on numerous conditions (determinants) - both internal (intrastate) and external ones, the latter coming from the international environment. In general, foreign policy is a function of a set of internal (intrastate) and international conditions present in the immediate and further international environment. Each of these groups is additionally divided into objective and subjective conditions. ${ }^{8}$ Still, not all the determinants of a country's foreign policy can be precisely classified as members of either group. This concerns first and foremost the geopolitical factor, which is a specific function of a country's internal and external geographical environment (objective conditions) as well as the conceptions of that country's foreign policy formulated in this context and their practical implementation (internal subjective conditions).

The reflection on the influence exerted by geographical conditions on the political activity of individuals and social groups, including foreign policies of countries, has a long history which dates back to ancient Greece, but the term "geopolitics" itself appeared only toward the end of the 19th century. ${ }^{9}$ The leading representatives of classical geopolitics, e.g. Swede Rudolf Kjellen, Englishman Halford Mackinder and Germans Friedrich Ratzel and Karl Haushofer, highlighted geographical determinism to explain and justify the foreign policies of countries, including their competition and expansive actions as well as

${ }^{8}$ See more in R. Zı̨̨BA: Uwarunkowania polityki zagranicznej. W: Wstęp do polityki zagranicznej państwa. Red. R. Zį̨BA. Toruń 2004.

${ }^{9}$ It was first used in 1899 by Swedish lawyer Rudolf Kjellen. 
conducting politics in terms of Realpolitik..$^{10}$ The German geopolitical doctrine, the main representative of which was Karl Haushofer, put forward a thesis that the development trends and political expansion of countries were geographically determined. ${ }^{11}$

Though classical geopolitics was discredited during World War II and the geopolitical factor significance in the shaping of the security policies of countries has slightly diminished in recent decades, i.a. due to the application of new military technologies (technology has defeated geography) and the intensification of the interdependence and globalisation processes (opinions that geoeconomics has defeated geopolitics), ${ }^{12}$ the geographical location of countries and other geographical factors (first and foremost natural resources as well as the lie of the land, the climate and the shape of borders) still play a very important role in the security policies of countries. The broadly defined geopolitical factor, including geopolitical notions, greatly influences the perception of international reality both by the decision makers of a country's foreign policy and the individual members of a particular society.

There is no universally accepted definition of geopolitics in geopolitical literature. The broadest approach defines geopolitics as geographical conditioning and explaining of political processes as well as searching for connections between the geographical space and political phenomena and processes, in particular investigating the influence of geographical factors on the foreign policies of countries. ${ }^{13}$ A slightly narrower definition of geopolitics states that it constitutes research on the foreign policies of countries and international relations from the geographical perspective. ${ }^{14}$ According to Leszek Moczulski, geopolitics deals with the changing balance of forces in an unchanging space. ${ }^{15}$ Geopolitics is characterised by a conviction that certain timeless truths or laws derived from the observation of the balance of forces are right. ${ }^{16}$ Stanisław Bielen and Andrzej Skrzypek write that the essence of Polish geopolitics is constant reflection on

${ }^{10}$ See L. Sykulski: Geopolityka..., p. 61 and subs. pages.

${ }^{11}$ See more in A. Wolff-PowęSka: Doktryna geopolityki w Niemczech. Poznań 1979, p. 131 and subs. pages.

12 The geoeconomic approach to international relations research assumes that the main hazards to a country's security are the economic ones. Unlike classical geopolitics, this approach puts forward a thesis that geographical location is not the most important aspect. The superior factor is the economic potential, which determines the rank and power in a given space, and every economic power strives to translate its power into political influence. See Geoekonomia. Red. E. HaliżaK. Warszawa 2012.

${ }^{13}$ See more in C. Jean: Geopolityka. Przeł. T. Orlowski. Wrocław 2003; C. Flint: Wstęp do geopolityki. Przeł. J. Halbersztat. Warszawa 2008; J. РотUlski: Wprowadzenie do geopolityki. Gdańsk 2010; L. SyKULSKI: Geopolityka..., p. 16-17.

14 Ibidem.

15 L. Moczulski: Geopolityka. Potega w czasie i przestrzeni. Warszawa 1999, p. 75.

16 S. Bieleń: Czas próby w stosunkach międzynarodowych. Warszawa 2017, p. 44. 
Poland's position in the changing balance of forces in the international arena, mainly with Russia's participation to the East and Germany's to the West. ${ }^{17}$

I reckon that the contemporary essence of the geopolitical factor as a very important determinant of the foreign policies of countries is the conceptions and objectives derived from a given country's geographical location for its internal and international actions. Various politicians, analysts and political parties can use the same geographical location to derive entirely different conceptions regarding the perception of the national interest as well as the proposed and implemented security policy. The geopolitical location does not determine eternal friends or eternal enemies, as exemplified by the policy of reconciliation between France and the FRG in the subsequent decades after World War II. The location of a country is a very important determinant of its internal and foreign policies, but one must remember that the policy implemented in the context of that country's geopolitical location depends on the subsequent groups ruling that country and the media that support them. One society can demonstrate various assessments of a country's geopolitical location - and it usually does. This is exemplified by the Poles' diversified assessments of Poland's geopolitical location, mainly its situation between Germany and Russia. Some viewed it as "Poland's curse" - a hopeless situation not to be overcome. Adam Balcer and Kazimierz Wóycicki write: "The concept of 'Polish geopolitics' in our tradition meant the virtually hopeless location of Poland between two enemy superpowers: Germany (previously Prussia and Austria) and Russia. For many decades, Polish geopolitics was a synonym of that insurmountable hopelessness." ${ }^{18}$ To others, Poland's geopolitical location in the post-Cold War period was the country's chance to develop and play the role of an important subject between the East and the West, ${ }^{19}$ a "keystone" or a "sagacious agent" between the two parts of Europe..$^{20}$ However, that chance has not been taken by the decision makers of Polish politics. Those diversified assessments were expressed in geopolitical conceptions as well as geopolitical codes, generated and spread among the public by politicians, experts and journalists. ${ }^{21}$ A geopolitical code is defined as the way a given country positions itself in relation to the world. That code consists of i.a. the following assumptions: a) Who are our present and potential

17 Wstęp. W: Geopolityka w stosunkach polsko-rosyjskich. Red. S. Bieleń, A. SkrzyPeK. Warszawa 2012, p. 8.

18 A. Balcer, K. Wóycicki: Polska na globalnej szachownicy. Warszawa 2014, p. 77.

19 See M. Dobroczyński: Między mocarstwami. Warszawa-Toruń 1996.

${ }^{20}$ S. Bieleń: Pozycja geopolityczna Polski. W: Polska w stosunkach międzynarodowych.

Red. S. Bieleń. Warszawa 2007, p. 28; P. Eberhard: Polska i jej granice. Lublin 2004, p. 278; P. GRudziński: Państwo inteligentne. Polska w poszukiwaniu międzynarodowej roli. Torun 2008, p. 10; K. ŁastaWski: Dylematy wspótczesnej polskiej racji stanu. W: Polityka zagraniczna Polski w zmieniajacym się tadzie międzynarodowym. Wybrane problemy. Red. R. ZięBa, T. Pawıuszko. Toruń 2016, p. 47.

${ }^{21}$ C. Flint: Wstęp do geopolityki..., p. 72 and subs. pages. 
allies? b) Who are our present and potential enemies? c) How can we oppose our potential enemies? d) How shall we justify these assumptions to our own public opinion and others? ${ }^{22}$ The geopolitical code forms one base for the international activity of a country's political decision makers and is utilised to interpret the phenomena and processes taking place in the international environment, first and foremost in the neighbouring countries. The shaping of geopolitical ideas, conceptions, doctrines and programmes is conditioned not only by objective factors (e.g. a country's geographical location, resources or economic potential), but also - and to a greater extent - by subjective ones (e.g. the historical experience and the related perception of hazards).

The concept "strategic culture" has a broader scope, determined by history and geopolitics, than "geopolitical code". Stephen F. Szabo reckons that a nation's strategic culture is an aspect of its general political culture (a result of mutual impacts of history, geography, politics, economy and culture) which concerns the national security policy, including convictions pertaining to national interests, the world, the nature of the international system as well as the causes and effects of the instruments used by the country in its foreign policy. ${ }^{23}$ The perception of the international environment and the social attitudes toward other countries and nations depend first and foremost on the historical experience (historical memory) ${ }^{24}$ the implemented historical policy and the political and strategic culture as well as the society's education level, hierarchy of values, religious beliefs and dominant ideology.

\section{Certain conditions of Poland's geopolitical location in the post-Cold War period}

In the years 1989-1993, Poland found itself in an entirely new geopolitical situation. The number of its neighbours increased from three in 1989 (the USSR, Czechoslovakia and the GDR) to seven at the beginning of 1993 (the

${ }^{22}$ Ibidem; L. SykulSki: Geopolityka..., p. 48-51.

${ }^{23}$ S.F. Szabo: Na rozstajach dróg. Kryzys w stosunkach niemiecko-amerykańskich. Przeł. K. Konkosz. Warszawa 2006, p. 87.

${ }^{24}$ Agata Włodkowska-Bagan justifiably argues that historical memory very often means the way a given incident was remembered by the majority of a given community, not the true course of events. Historical memory may also be a selective record of past events, thus turning into historical oblivion. A. WŁodKowska-Bagan: Kultura strategiczna Polski. W: Polityka zagraniczna Polski..., p. 57. One must highlight that a characteristic feature of historical policies implemented by groups ruling the individual countries is the selective approach to historical events and their excessively one-sided interpretation. 
FRG, the Russian Federation via the Kaliningrad Oblast, Lithuania, Belarus, Ukraine, Slovakia and the Czech Republic). Poland had borders acknowledged by all its neighbours, which was expressed in the treaties it signed with them in the years 1990 - 1994. This way, Poland found itself in an entirely new geopolitical situation in a very short time. The new situation was viewed both by its ruling groups and the majority of its society as much more beneficial than the previous situation in the bipolar system the European part of which was the Yalta-Potsdam system. ${ }^{25}$

The first government formed by the Solidarność [Solidarity] movement with Tadeusz Mazowiecki as the Prime Minister redefined Poland's reason of state both in its internal aspect (market economy and parliamentary democracy) and its external aspect (independence - security — development). The essence of the new Polish reason of state implemented via the foreign policy was the regained independence in the relations with the Soviet Union and its consolidation after USSR dissolution, building the country's security, supporting the nation's and the society's economic and civilisational development as well as strengthening Poland's position in the international arena, especially in Europe. ${ }^{26}$ One direct consequence was the new objectives accomplished in the Polish foreign policy, including the priority of the Western direction and the effort to change alliances and connect Poland institutionally with Western Europe (a permanent connection with the West) as well as a new Eastern policy, including striving to arrange new, partnership-based relations with the Soviet Union and then with its main formal successor, the Russian Federation, after USSR dissolution at the end of 1991.

One of the consequences of the great systemic and geopolitical transformation in Poland's immediate international environment after 1989 was the great weakening of Russia's influence in Central Europe and the gradual strengthening of Germany's role in that subregion. The influence of the United States in that part of Europe, predominantly in the political and security areas, also kept increasing, first and foremost due to the launching of the NATO enlargement process. The zone of influence of the Russian Federation as the main successor of the USSR in the international law aspect was pushed away from the Elbe River and behind the Bug River. For the first time in modern history, Germany and Russia became separated not only by the territory of Poland, but also by the countries which emerged beyond Poland's eastern border due to USSR dissolution: Ukraine, Belarus, Lithuania, Latvia and Estonia. Though Poland bordered

${ }^{25}$ See K. Łastawski: Pozycja geopolityczna Polski w Europie po rozpadzie bloku radzieckiego. W: Bezpieczeństwo międzynarodowe. Polska - Europa - Świat. Księga Jubileuszowa dedykowana Profesorowi Ryszardowi Ziębie z okazji czterdziestolecia pracy naukowej. Red. J. Zając, A. WŁodkowska-Bagan, M. KaCzmarski. Warszawa 2015.

${ }^{26}$ See more in: R. KuŹniar: Droga do wolności. Polityka zagraniczna III Rzeczypospolitej. Warszawa 2008. 
on Russia in the east only via the Kaliningrad Oblast, Russia and Ukraine were its most important eastern neighbours.

The Western direction in the Polish foreign policy after 1989 was supposed to be implemented first and foremost via close cooperation and permanent agreement with Germany, which was reunified in 1990 and constituted the strongest country in the economic and political structures of Western Europe as well as the most important ally of the United States in continental Europe (the notion "through Germany to Europe"). A strategic objective in the Western direction of the Polish foreign policy, consistently pursued in subsequent years, was membership in the European Union and the NATO. Poland eventually managed to obtain the NATO membership first, in 1999, and it became an EU Member State in 2004. When Poland entered the North Atlantic Alliance, the role of the United States in the Polish foreign policy significantly increased, predominantly in the political and security areas. Poland's security policy underwent Americanisation. ${ }^{27}$ Due to the USA's leading role in the Polish security policy, Poland's security and the Polish-Russian relations became a function of the American-Russian relations to a considerable extent. The Polish-German relations were determined by the German-American relations to a much smaller extent.

The Ukrainian crisis and conflict in 2014 and subsequent years significantly worsened Poland's geopolitical situation. The sense of external security considerably diminished in most Poles, while the sense of a hazard posed by Russia greatly increased. 2014 was an incredibly important turning point in the Polish security policy. The National Security Strategy of the Republic of Poland signed by the President of Poland on 5 November 2014 included provisions from which it appeared that, in view of the crisis and then conflict in eastern Ukraine, including Crimea incorporation by Russia and the latter's support for the proRussian separatists in eastern Ukraine, Russia was the main military hazard to Poland's security. ${ }^{28}$

One of the most characteristic features of Poland's relations with Russia and Germany in the post-Cold War period was the asymmetry of the countries, which was unfavourable to Poland. Although Poland's economic development has significantly accelerated, which includes its GDP growth in the last 30 years, Poland was a middle-sized country in the post-Cold War system, while Germany and Russia were superpowers. The power of a country is built both from material components (the physical power - i.a. the economic, military and demographic potential, the surface area, the degree of dependence on foreign resources) ${ }^{29}$ and

27 See R. ZięBa: Polityka zagraniczna Polski w strefie euroatlantyckiej. Warszawa 2013, p. 118 and subs. pages.

${ }_{28}$ The National Security Strategy of the Republic of Poland. Warszawa 2014 - www. mon.gov.pl (accessed: 29.11.2014).

${ }^{29}$ H. Morgenthau: Polityka między narodami. Walka o potęę i pokój. Przeł. R. Weoch. Warszawa 2010; P. Buhler: O potędze w XXI wieku. Przeł. G. Majcher. Warszawa 2014. 
non-material elements (e.g. prestige, national morale, diplomacy quality, government quality). ${ }^{30}$ Bearing in mind the material and non-material components of power, it seems very accurate to say that power in international relations is a country's ability to use its material and non-material resources in a manner influencing the behaviour of other countries according to the expectations of the decision makers implementing that country's foreign policy. ${ }^{31}$ When one considers the material and non-material power of Poland, Germany and Russia, one sees that Germany's and Russia's capabilities of influencing the behaviour of other countries were much greater than Poland's capabilities in this regard.

For many decades, the main attribute of the superpower position held by the FRG has been its economic potential. Germany is Europe's greatest economic power and one of the greatest in the world. In 2017, the FRG took the fourth place in the world concerning GDP at current prices (3.677 trillion USD), after the United States (19.390 trillion USD), the People's Republic of China (12.237 trillion USD) and Japan (4.872 trillion USD). ${ }^{32}$ The FRG occupied the first position among the world's leading exporters throughout the years (that position has belonged to the PRC for a few years). In 2017, the value of German export was 1.279 trillion EUR, while the import reached 1.34 trillion EUR. Germany's trade surplus in 2017 reached approx. 245 billion EUR. ${ }^{33}$ Not only was Germany the greatest economic power in Europe, but it also became the most influential European country in politics. That process considerably intensified in the second decade of the 21 st century. ${ }^{34}$

Though Russia's international position significantly weakened in the 1990s, it played the role of a Eurasian superpower in the entire post-Cold War period. That position was greatly strengthened in the first and second decade of the 21st century. Russia's geopolitical location and numerous other attributes let it play one of the leading roles both in Asia and Europe (42.4\% of Europe's territory and over $28.4 \%$ of Asia's territory belong to Russia). Russia is the richest in natural resources among all the countries of the world. It is one of the biggest

${ }^{30}$ Ibidem, p. 136 and subs. pages. Joseph S. Nye Jr writes about soft power as an incredibly important component of a country's overall power influencing the effectiveness of its foreign policy. J.S. Nye: Soft Power. Jak osiagnać sukces w polityce światowej. Przeł. J. ZABOROWSKI. Warszawa 2007.

${ }_{31}$ M. SuŁeK: Dynamika zmian parametrów potęgi państw regionu Azji i Pacyfiku 1985 2015. W: Region Azji i Pacyfiku w latach 1985-2015. Ciagłość i zmiana w regionalnym systemie międzynarodowym. Red. A. JARCZeWsKA, J. ZajĄCZKOWSKi. Warszawa 2016, p. 577.

32 "Rocznik Strategiczny" 2018/2019, T. 24, p. 444 and subs. pages.

33 https://www.bankier.pl/wiadomosc/Niemiecki-eksport-srubuje-rekordy-7571395.html (accessed: 29.08.2018).

${ }^{34}$ See more in M. Stolarczyк: Wzrost mocarstwowej pozycji Niemiec $w$ drugiej dekadzie XXI wieku. W: Między idea, pasja a działaniem. Księga jubileuszowa dedykowana $d r$. hab. Marianowi Mitrędze. Red. P. Grzywna, J. Lustig, N. Stępień-Lampa, B. ZasęPa. Katowice 2017. 
exporters of natural gas and crude oil. In 2012, Russia's GDP exceeded 2 trillion USD. ${ }^{35}$ Russian export in 2012 reached 529 billion USD and the import equalled 335 billion USD. At the beginning of the second decade of the 21st century, Russia took the eighth place in global export and the 16th place in global import. ${ }^{36}$ In 2014, before the West imposed sanctions on Russia for Crimea incorporation and supporting the pro-Russian separatists in Donbass, Russia's nominal GDP according to IMF data was 1.860 trillion USD. Russia occupied the 10th place worldwide concerning nominal GDP (the value of goods and services produced in a country throughout the year). Poland was 23rd in the same ranking, with its nominal GDP reaching approx. 548 billion USD. Due to the sanctions imposed on Russia in 2014 and prolonged in subsequent years as well as very serious drops of crude oil and gas prices on the international stock exchange markets in the years 2015-2016, Russia's GDP decreased in that period by approx. 3\%. In 2017, however, it increased by approx. 1.5\%. According to some estimations, Russia's GDP at current prices in 2017 reached nearly 1.578 trillion USD. ${ }^{37}$ In 2018, its GDP increased by 2.3\% in relation to the 2017 value. Also in 2018, Russia's foreign trade turnover equalled 692.6 billion USD. Russian export in 2018 increased by $25.6 \%$ in comparison with 2017 and reached 452.1 billion USD, while the import increased by $5.1 \%$ and reached 240.5 billion USD. ${ }^{38}$ It must at least be mentioned here that the Russian Federation is a permanent member of the UN Security Council and possesses the world's second biggest nuclear forces after the USA. Russia's military expenditure in 2017 slightly exceeded 66 billion USD (Germany spent approx. 44 billion USD and Poland spent a little more than 10 billion USD on that purpose). ${ }^{39}$ The USA's military expenditure in the same year reached almost 610 billion USD. ${ }^{40}$

Due to the asymmetry of potential (power) and of the international roles between Poland, Germany and Russia, Poland's geopolitical location and the historical experience, Germany's and Russia's roles in Polish politics were definitely greater than Poland's role in German and Russian politics. This manifested itself both in the conceptions and programmes of the foreign policies of those countries and their political practice. Still, considering the role in the politics of Germany and Russia, Poland played a much greater role in Germany's politics

35 "Rocznik Strategiczny" 2013/2014, T. 19, p. 398.

${ }^{36}$ Polska 2013. Raport o stanie handlu zagranicznego. Polish Ministry of Economy. Warszawa 2013, p. 13.

37 "Rocznik Strategiczny" 2018/2019, T. 24, p. 452.

${ }^{38}$ R. STAŚKIEWiCZ, M. WALCZAK: Ocena sytuacji w handlu zagranicznym z 2018 roku. Division of Macroeconomic Analyses and Forecasts in the Department of Economic Analyses. Ministry of Entrepreneurship and Technology. DAG_Ocena_sytuacji_w_handlu_zagranicznym_2018.pdf-Adobe Acrobat Reader DC (accessed: 21.11.2019).

39 "Rocznik Strategiczny" 2018/2019, T. 24, p. 456 and subs. pages.

${ }^{40}$ Ibidem, p. 464. 
(including the programme assumptions made by FRG governments) than in Russia's politics. An example is the CDU/CSU-SPD coalition agreement signed in March 2018, which highlights several times the need for enhancing Germany's cooperation with Poland. ${ }^{41}$

Agata Włodkowska-Bagan indicates that Poland's history, including the colonial rule of the First [I RP] and Second [II RP] Polish Republic over Eastern Europe, which is still frequently called "the Eastern borderlands" [Kresy], as well as Poland's geopolitical location between two countries playing the roles of superpowers and USSR dissolution played the main role in the shaping of the Polish strategic culture in the post-Cold War period. ${ }^{42}$ The same author lists the following features of the Polish strategic culture: the Russian and German syndrome and related suspiciousness (distrust) toward the two big neighbours, ${ }^{43}$ including a feeling that they strengthen their cooperation over the Poles' heads (the Rapallo syndrome), as well as the syndrome of betrayal by allies in 1939 and the victim syndrome (e.g. blaming others for the country's failures). ${ }^{44}$ The abovementioned features of the Polish strategic culture affected the perception of challenges and hazards by the decision makers of the Polish foreign policy in the post-Cold war period and their actions in this scope.

The features of a strategic culture, including the Polish one, are manifested in the conceptions of the foreign and security policies because foreign policy conceptions are among the most important subjective internal conditions governing a country's foreign policy. Foreign policy conceptions and the objectives formulated on their basis stem from the national and state interests; more precisely, they are derived from the way those interests are understood (interpreted) and carried out by the subsequent decision makers of a country's foreign policy. The two traditional geopolitical conceptions present in the Polish political thought since the beginning of the 20th century regarding Poland's foreign policy, the latter implemented first and foremost in between Russia and Germany, are: the incorporation (realistic) conception related to Roman Dmowski and the federation (Promethean) conception connected with Józef Piłsudski. The realistic conception assumed the restoration of the Republic of Poland covering first and foremost the ethnically Polish territory (i.e. one inhabited by ethnic Poles) as well as the lands where Poles were a minority but dominated in terms of culture and ethnically non-Polish lands necessary for communication-relat-

${ }^{41}$ Ein neuer Aufbruch für Europa. Eine neue Dynamik für Deutschland. Ein neuer Zusammenhalt für CDU,CSU und SPD. Koalitonsvertrag zwischen CDU,CSU und SPD dynamic.faz.net/download/2018.koalitionsvertrag.pdf (accessed: 9.08.2018).

42 A. Weodkowska-Bagan: Kultura strategiczna Polski..., p. 58 and subs. pages.

${ }^{43}$ One extreme manifestation of that was Jarosław Kaczyński's statement at the beginning of September 2010 that Poland under the rule of the PO/PSL coalition was "a RussianGerman condominium".

${ }^{44}$ Ibidem, p. 60 and subs. pages. 
ed, strategic and economic purposes. In R. Dmowski's conception, which he modified in the following years, Poland's security in the East was to be based on close relations with Russia, also at the cost of the independence aspirations and efforts of Belarusians and Ukrainians. He saw the main hazard to Poland in Germany, the civilisational advantage of Germans over Poles and a possible German expansion into the ethnically Polish lands (i.a. Greater Poland, Gdańsk with Pomerania and at least a part of Upper Silesia). ${ }^{45}$ The federation conception deemed Russia the main enemy. It assumed support for the emergence of independent national states in the Russian Empire area (Prometheism): first of all, the Lithuanian and Ukrainian states, as well as, to a lesser extent, a Belarusian state. Then, those nations and their organisational structures were to be included in a system of alliances (an Eastern European union) or a federation (based on separate statehood or broad self-government autonomy) in which Poland would be the leader (a restoration of the pre-1772 Republic of Poland in a new version). Piłsudski wished to establish a federation of the nations which had belonged to the First Republic of Poland and wanted to break away from Russia. ${ }^{46}$ The federation (Promethean) conception referred to the Jagiellonian paradigm, putting the emphasis on Poland's civilisational mission in the East. ${ }^{47}$ In practice, Piłsudski's plans of creating a federation of four nations - Poles, Lithuanians, Belarusians and Ukrainians - based mainly on the pre-partition Republic of Poland with a possible expansion were not carried out. One of the main reasons was the fact that the nations supposed to become the federation members did not want such solutions and objected to them, striving to achieve their own independent statehoods. Lithuanians, Ukrainians and, to a lesser extent, Belarusians demonstrated mainly anti-Polish attitudes, manifested their national and political identity and strove to break away from Poland instead of cooperating with it more closely. ${ }^{48}$ The best example of the lack of conditions for a practical

${ }^{45}$ See R. Dmowski: Niemcy, Rosja i kwestia polska. Wrocław 2000 (first ed. 1908); L. Moczulski: Geopolityka..., p. 557 and subs. pages.

${ }^{46}$ L. MoczUlski: Geopolityka..., p. 560 and subs. pages.

47 A. Czarnocki: Koncepcje polityki zagranicznej Polski. W: Międzynarodowe stosunki polityczne. Red. M. Pietraś. Lublin 2006, p. 617-618. Rafał Juchnowski justifiably argues that the founding idea for the Polish political thought throughout history was Jagiellonism combined with federalism and the superpower conception. The main components of the Jagiellonian paradigm were i.a.: Poland's key role in the region situated between the Baltic Sea, the Black Sea and the Adriatic Sea, the anti-Russian attitude, the sense of a civilisational mission and the bulwark conception. R. JuchnowsKi: Miejsce geopolityki w polskiej myśli politycznej...

48 A. Marszalek: Polskie dyskusje o integracji europejskiej po II wojnie światowej $w$ historycznej perspektywie porównawczej. Wybrane zagadnienia. Torun 2010, p. 218 and subs. pages; Adolf Bocheński writes that the Jagiellonian paradigm, associated by Poles with freedom, tolerance and federalism for Ukrainians or Lithuanians, was actually a synonym of Polish imperialism as well as cultural and economic hegemony. After: R. JUCHNOwsKI: Miejsce geopolityki w polskiej myśli politycznej..., p. 263. 
implementation of the federation conception was the Polish-Ukrainian war for Eastern Galicia (including Lviv) and the turn of 1918 and 1919, which defeated the independence aspirations of Galician Ukrainians and established the Polish rule over the land up to the Zbruch River. J. Piłsudski's Kiev expedition (preventive war) was not successful, mainly because Ukrainians did not grant those actions their mass support.

Another conception stemming from Poland's geopolitical location between Russia and Germany was Intermarium. It became a subject of foreign policy for virtually all the governments which ruled the Second Republic of Poland and conducted the policy of "two enemies." neutralise the Russian and German influence in Central and Southern Europe by establishing a political and economic association of countries reaching from the Baltic Sea to the Black Sea and the Aegean Sea, in which Poland would play a leading role. The conception was never carried out i.a. due to the tensions in the Polish-Lithuanian and Polish-Czechoslovakian relations. ${ }^{50}$ The Intermarium conception was highly appreciated by many Polish politicians, analysts and journalists in the post - Cold War period. It was put forward predominantly by politicians connected with two political parties: Konfederacja Polski Niepodległej [the Confederation of Independent Poland] ${ }^{51}$ and Prawo i Sprawiedliwość [Law and Justice] (PiS). The latest version of that conception, modified to include the countries situated between the Baltic Sea, the Black Sea and the Adriatic Sea, has been promoted by President of Poland Andrzej Duda and subsequent PiS governments as Trimarium [Trójmorze] or the ABC conception since 2015. Although PiS politicians underline that Trimarium is not to be connected with Intermarium because it is not geopolitical in nature and its objectives are purely pragmatic (first and foremost the building of a North-South energy corridor), it is hard to accept this stance fully. Trimarium, presented as an infrastructure project and not a political one, was established in 2015 on the initiative of the Presidents of Poland and Croatia: Andrzej Duda and Kolinda Grabar-Kitarović. It gathers 12 countries: Austria, Bulgaria, Croatia, the Czech Republic, Estonia, Hungary, Latvia, Lithuania, Poland, Romania, Slovakia and Slovenia. Despite the declared infrastructural and non-geopolitical nature of Trimarium, it is easy to conclude that the main motives of that project, carried out predominantly on the initiative of Polish authorities, include the effort to diminish Germany's role in the EU and neutralise certain implications of the German-Russian coopera-

49 See A. Skrzy pex: Geopolityka "Międzymorza" i jej wptyw na stosunki Polski z Rosja. W: Geopolityka w stosunkach polsko-rosyjskich. Red. S. Bieleń, A. SKrzypek. Warszawa 2012.

50 A. MarszaleK: Europejska idea integracji międzynarodowej w perspektywie historycznej. Toruń 2008, p. 180 and subs. pages.

${ }^{51}$ When Leszek Moczulski promoted Trimarium, he indicated 18 countries which could participate in that conception. L. Moczulski: Geopolityka..., p. 543-544. 
tion on the increase of Russian gas supplies to Germany and other countries, i.a. by the plans of the Trimarium Member States to purchase more gas imported from the USA. ${ }^{52}$

Poland's Eastern policy after 1989 and even more after USSR dissolution referred to the Promethean conception in its significantly modified version which was created after World War II by Jerzy Giedroyc and Juliusz Mieroszewski editors of "Kultura" [Culture], a monthly published by the Polish immigrant community in Paris. The core of that conception, contained in the acronym ULB (Ukraine, Lithuania, Belarus), was an assumption that those countries were Poland's natural allies. The editors of "Kultura" were in favour of developing the best possible relations between Poland and Russia, but not at the cost of the neighbours, especially Ukraine. Independent Ukraine was perceived as the main barrier preventing the restoration of the Russian Empire. ${ }^{53}$ It should be mentioned here that even though subsequent Polish governments after 1989 referred to the ULB conception, they did not support all of its elements equally. This concerned in particular the postulate formulated by J. Giedroyc which he highlighted after 1989: the need to normalise the Polish-Russian relations and make them as good as possible as well as strive for "Russia's Europeanisation." ${ }^{54}$ One characteristic feature of the Polish Eastern policy in the post-Cold War period was the diversified understanding and interpretation of the ULB conception.

The Promethean vision, Intermarium and the ULB conception all influenced Poland's foreign policy in the post-Cold War period, albeit with varying intensity depending on the exact time..$^{55}$ Their mutual element was the search for the geopolitical possibilities of shaping the regional international system in Poland's

52 The first Trimarium summit took place in Dubrovnik (25-26 August 2016). The final declaration adopted there indicated the main objectives of cooperation in such areas as gas power supply, transport, digital competition and economy. See M. Sienkiewicz: Koncepcja Trójmorza w polityce zagranicznej Polski po 2015 r. "Dyplomacja i Bezpieczeństwo" 2016, nr 1; A. BALCER: Trójmorze - myślenie życzeniowe czy Realpolitik? "Dialog” 2017, nr 1. The second Trimarium summit was held in Warsaw (6-7 July 2017) with the participation of President of the United States Donald Trump, the third one was organised in Bucharest (17-18 September 2018) and the fourth one took place in Ljubljana (5-6 June 2019).

${ }^{53}$ I. Hofman: Polska-Niemcy-Europa. Program zachodni paryskiej "Kultury". Lublin 2009, p. 32 and subs. pages.

${ }^{54} \mathrm{~J}$. Giedroyc was afraid that the fight with Sovietism, Sovietisation and communism might transform into a fight with Russia. He remarked that Poland was doomed to cooperation with Russia regardless of that country's form, so the relations needed to be normalised without showing unnecessary humility or arrogance, which was unfortunately Poland's constant trait. Teczki Giedroycia. Oprac. I. Hofman, L. Unger. Lublin 2010, p. 75, 88-89.

${ }_{55}$ Rafał Juchnowski writes, "The Piast_Jagiellonian paradigm, the bulwark conception and the 'missionary' nature of Poland's role in relation to its eastern neighbours became the foundation for Polish geopolitics again after the fall of communism. Of course, their form was much subtler than in the previous periods". R. Juchnowski: Miejsce geopolityki w polskiej myśli politycznej..., p. 478-479. 
subregion in opposition to Russia and, although to a much lesser degree, in opposition to Germany.

\section{Main stages of Poland's relations with Germany in the post-Cold War period and their characteristics}

Poland's relations with Germany in the post-Cold War period can be divided into several phases (stages). Each of them was specific i.a. due to the scope of convergent and divergent interests as well as the defined objectives accomplished in the Polish-German bilateral relations and in the bi- and multilateral relations of either country with other participants of international relations. In a somewhat simplifying manner, one can divide Poland's relations with the FRG in the years 1990-2019 into the following phases:

1. The years 1990 - 1991, when new political and legal foundations were adopted. The main ones were two signed treaties: the German-Polish Border Treaty (14 November 1990), which confirmed the border between the two countries, and the Polish-German Treaty of Good Neighbourhood and Friendly Cooperation (17 June 1991) ${ }^{56}$;

2. The years 1991-1998, characterised by development of bilateral cooperation in nearly all fields. The disputable issues emerging in that period did not constitute a serious burden to the Polish-German interstate relations, which was manifested particularly by Poland via the "Polish-German community of interests" formula ${ }^{57}$;

3. The years 1998-2004, when the Polish-German relations were significantly determined by Poland's accession negotiations with the European Union. At that time, beside cooperation in many fields, significant differences in the stances of both governments and societies came to the fore. They concerned some areas of the EU accession treaty negotiated by Poland (e.g. free movement of labour or trade in land), with certain historical aspects in the background (a dispute concerning the Centre Against Expulsions construction plans put forward by the management of the Federation of Expellees and compensation claims of the Prussian Trust against Poland), as well as important international issues (e.g. resolving the Iraqi problem, subsequent modifications of the functioning of EU integration structures as well as perception

${ }^{56}$ See the text of both treaties in Polska-Niemcy: dobre sasiedztwo i przyjazna wspótpraca. Red. J. BARCZ, M. Tomala. Warszawa 1992, p. 19-20 and 24-34.

${ }^{57}$ See more in M. StolarCzyK: Wokót formuly "polsko-niemiecka wspólnota interesów". "Przegląd Zachodni" 1998, nr 1. 
of Russia's role in international relations and the nature of the policy toward that country $)^{58}$;

4. The years 2005-2007, when the Polish-German relations worsened considerably, first and foremost due to another intensification of disputes over historical issues as well as new elements in Poland's historical policy during the rule of the government formed by Prawo i Sprawiedliwość and its coalition partners. The "German problem" recurred in the Polish foreign policy, mainly because of the reappearance of historical issues and burdens in the political discourse of both countries. In Poland, however, representatives of the ruling groups became much more involved in the discussion than did their counterparts in Germany. The historical policy of PiS significantly determined the Polish-German relations. Analysts supporting the PiS rule simultaneously argued that Germany's role in Polish politics after 1989 was greatly overestimated, while Poland's role in German politics was underestimated. ${ }^{59}$ It was i.a. for those reasons that the Piast (Western) direction in the Polish foreign policy weakened at that time, while the Jagiellonian (Eastern) direction strengthened. ${ }^{60}$ According to the foreign policy conception put forward by those advocating the implementation of a political project called the Fourth Republic of Poland [IV RP], solving the problems appearing in the Polish bi- and multilateral relations, especially in the relations with Russia, Germany and the European Union, was seen mainly from the angle of a conflict of interest (so-called policy of dignity and rising from the knees) ${ }^{61}$;

5. The years 2008 - 2015, characterised by another strong pro-German turn in the Polish foreign policy and an increase of Germany's role in Polish politics (so-called "bet on Germany"). This was caused mainly by the actions of the new government formed in November 2007 by the PO/PSL coalition with Donald Tusk as the Prime Minister and included i.a. the quietening of the disputes over historical issues (e.g. the construction of the Centre Against Expulsions carried out in Berlin since 2005 under a changed name of a "Visible Sign"), ${ }^{62}$ diminishing the controversy around other disputable matters (e.g.

58 See more in M. Stolarczyк: Zbieżność i różnice interesów w stosunkach polsko-niemieckich w latach 1989-2009. Katowice 2010; Z. MAZUR: Centrum przeciwko Wypędzeniom (1999-2005). Poznań 2006; Erwachsene Nachbarschaft. Die feutsch-polnischen Beziehungen 1991 bis 2011. Hrsg. D. Bingen, P.O. Loew, K. Ruchniewicz, M. Zybura. Wiesbaden 2011.

59 M.A. Cichocki: Niemiecka polityka wobec Polski na nowych drogach? "Dialog" 2005/2006, nr 72-73, p. 32-33.

${ }^{60}$ M. Mróz: Między Polska piastowska a jagiellońska...

${ }^{61}$ See P. Grudziński: Państwo inteligentne. Polska w poszukiwaniu międzynarodowej roli. Torun 2008, p. 120 and subs. pages.

${ }^{62}$ In 2013, the construction of the Documentation Centre for Twentieth-Century Expulsions was commenced in Berlin. The project was first carried out as the Centre Against Expulsions and then under the name of a Visible Sign. 
the construction of Nord Stream I, a German-Russian gas pipeline running along the bottom of the Baltic Sea, with the participation of concerns from other Western European countries) and reducing the role of NATO in expeditions (Poland and Germany did not participate in NATO's military operation in Libya in 2011). The effort made by the governments of both countries resulted in a considerable improvement of the Polish-German intergovernmental relations. The relations between the governments led by Chancellor Angela Merkel and Prime Minister Donald Tusk benefited from a better atmosphere suitable for resolving disputable issues. When a new government was formed in the autumn of 2014 by the PO/PSL coalition with Ewa Kopacz as the Prime Minister, Poland's policy toward Germany did not change;

6. Since the end of 2015, when, as a result of the parliamentary election held on 25 October 2015, PiS formed a new government in the middle of November 2015 with Beata Szydło as the Prime Minister. As highlighted in the PiS programme, one of the main objectives to be pursued by the new government was "restoration and then strengthening and protection of Poland's autonomous position in international politics and internal security." ${ }^{63}$ Striving to "restore Poland's autonomous position in the international arena", including in the relations with the EU and Germany, ${ }^{64}$ the government led by Prime Minister B. Szydło diminished Germany's role in the Polish foreign policy, which manifested itself i.a. in Germany's distant position in the exposé delivered by Polish Minister of Foreign Affairs Witold Waszczykowski in the Polish parliament at the end of January 2016, in which Poland's relations with Great Britain were highlighted more than those with Germany. Still, Minister Waszczykowski announced that the friendly relations with Germany would be continued. He said that it was the right time for a positive reflection on the community of interest in Europe as well as a good opportunity for a little stocktaking of the affairs in the neighbourhood. He also stated, "The Polish-German contacts will be better if accompanied by sincerity and openness instead of the occasionally pretended and superficial conciliatory tone." ${ }^{\prime 5}$ Even before becoming the Minister of Foreign Affairs in B. Szydło's government, Witold Waszczykowski said that the strategy of close cooperation with Germany pushed through by Radosław Sikorski for many years had ended in failure. ${ }^{66}$ In practice, the Polish-German

${ }^{63}$ Program Prawa i Sprawiedliwości 2014 - www.pis.org.pl/dokumenty?page=1 (accessed: 12.10 .2015$)$.

${ }^{64}$ Ibidem.

${ }^{65}$ Information on the Polish foreign policy tasks in 2016, presented by Polish Minister of Foreign Affairs Witold Waszczykowski in the Polish parliament on 29 January 2016 - http:// msz.gov.pl/aktualnosci/wiadomosci/minister_witold_waszczykowski_o_priorytetach_po kk1ej_dyplomacj1, p. II (accessed: 3.02.2016).

"Nie jestesmy eurosceptyczni. Rozmowa z Witoldem Waszczykowskim. "Rzeczpospolita", 3 November 2015. 
relations in the years 2016-2017 cooled considerably. German political scientist Kai-Olaf Lang wrote that they had entered a new phase. "The period of mutual understanding and closeness is behind us. Nowadays the tone of the debate is toughening and distrust is increasing — on both sides." ${ }^{97}$ The same author also said that the policy of the PiS government toward Germany oscillated between distrust and cooperation ${ }^{68}$. The main disputable issues in the Polish-German relations at that time included i.a.: the construction of Nord Stream II, the second line of the German-Russian gas pipeline running along the bottom of the Baltic Sea; the way of resolving the refugee and migration crisis in the EU; breaking the fundamental democratic principles in Poland by the politicians of PiS and the cooperating parties; demanding reparations from Germany by PiS politicians; and the growth of Germany's superpower position.

A slight improvement in the Polish-German relations took place in the years 2018 - 2019. In December 2017, Mateusz Morawiecki became Poland's Prime Minister. In January 2018, after a cabinet reshuffle, Jacek Czaputowicz became the Minister of Foreign Affairs. In his exposé delivered in the Polish parliament on 21 March 2018, Minister J. Czaputowicz said i.a. that friendly relations with Germany were the precondition for the success of any positive projects put forward in the EU and that the Polish government wished to commence works on solving the issues on which the stances of the two countries differed ${ }^{69}$. A new tone of the relations with the FRG maintained by Mr Morawiecki's government included i.a. the decision not to emphasize reparations: that matter was to be considered by experts from both countries.

${ }^{67}$ K.O. LANG: Kłóćmy się, ale rozsądnie. "Rzeczpospolita”, 26 January 2016.

${ }^{68}$ K.O. Lang reckons that the PiS government has a strong sense of hazard and fear of new Germany which allegedly uses its dominant position in the EU to push Poland to the sidelines. PiS does not trust Germany and accuses it of an offensive policy of forcing through its own interests. At the same time, PiS acknowledges that there are many areas, especially in economy, where cooperation must be continued. Ekspert: polityka Polski wobec Niemiec oscyluje między nieufnościa a wspótpraca - http://wiadomosci.wp.pl/kat,1356,title,Ekspertpolityka-Polski-wobec-Niemiec-oscyluje-miedzy-nıeufnosia-a-wspołpraca,w1d,18379882,w1a domosc.html?ticaid=11323 (accessed: 15.06.2016).

Minister Jacek Czaputowicz o priorytetach polskiej dyplomacji w 2018 roku - http:// www.msz.gov/pl/pl/aktualnosci/wiadomosci/minister_jacek_czaputowicz_o_priorytetach_ polskie_dyplomacji_w_2018_roku, p. 11 (accessed: 25.04.2018). 


\section{Main areas of divergent interests in Poland's relations with Germany in the second decade of the 21st century}

The outcome of the Polish-German cooperation after 1989 concerning politics, economy and intersocial relations between Poles and Germans is definitely positive. Studies, press articles and politicians' speeches in both countries in nearly the last 30 years have rightly highlighted first and foremost the positive achievements and effects. However, a characteristic feature of all the stages of the Polish-German relations after 1989 was the simultaneous presence of convergent and divergent interests as defined by the subsequent ruling groups in Poland and Germany.

In the author's opinion, the most important areas of divergent interests as understood by the decision makers in the Polish and German foreign policies in the second decade of the 21st century were as follows:

1. The stances of Poland and Germany on the manners of solving the conflict in Ukraine. A characteristic feature of all the stages of the Polish-German relations in the post-Cold War period was the presence of significant differences in the two countries' Eastern policies, first of all toward Russia and Ukraine. ${ }^{70}$ During the Ukrainian conflict, the stances of the Polish and German governments on Russia became similar, but that convergence (which pertained predominantly to the causes of the Ukrainian crisis and conflict) ${ }^{71}$ was still accompanied by considerable differences. The main differences between the Polish and German stances on the Ukrainian crisis and conflict concerned:

- the degree of direct involvement of the Polish and German political circles in the Ukrainian revolution of 2014. No other country's politicians

70 See M. Stolarczyк: Polska i Niemcy wobec polityki wschodniej Unii Europejskiej i stosunków z Rosją w pierwszej dekadzie XXI wieku. "Rocznik Integracji Europejskiej" 2010, nr 4; M. Stolarczyк: Rosja w polityce Polski i Niemiec na przetomie pierwszej i drugiej dekady XXI wieku. Zakres zbieżności i różnicy stanowisk. "Studia Politicae Universitatis Silesiensis" 2014, T. 12; K. Malinowski: Polska i Niemcy w Europie (2004-2014). Różnice interesów - uwarunkowania i konsekwencje. Poznań 2015, p. 161 and subs. pages.

${ }^{71}$ Representatives of both countries' governments held President of Ukraine Viktor Yanukovych and the Ukrainian government led by Prime Minister Mykola Azarov responsible for the Ukrainian crisis because they had decided to suspend the preparations for signing the Ukraine-European Union Association Agreement. They also blamed the Russian authorities and President Vladimir Putin because of their effort to slow down the fast pace at which Ukraine was approaching the EU. Moreover, the Polish and German governments absolutely condemned Crimea incorporation by Russia and the latter's support for the pro-Russian separatist groups in eastern Ukraine. They also supported political and economic sanctions on Russia. See more in M. StolarczyK: Polska i Niemcy wobec kryzysu $i$ konfliktu ukrainskiego. W: Implikacje konfliktu ukraińskiego dla polityki zagranicznej $i$ bezpieczeństwa Polski. Aspekty polityczne, wojskowe, gospodarcze oraz społeczne. Red. K. Czornik, M. Lakomy, M. Stolarczyk. Katowice 2015. 
became involved in supporting the Ukrainian revolution of 2014 on such a scale or in such a direct, intense and uncritical manner as did Polish politicians;

- the political isolation of Russia in the international arena. Representatives of subsequent Polish governments advocated imposing the most severe political and economic sanctions possible on Russia. Still, Russia relatively quickly ended its political isolation in the relations with Western countries which had begun in the middle of 2014, and Germany significantly contributed to that fact (the visits of Chancellor A. Merkel and Minister of Foreign Affairs Frank-Walter Steinmeier in Russia in 2015);

- the degree of involvement of the Polish and German governments in the de-escalation of the conflict in eastern Ukraine. German diplomacy became involved to the largest extent of all the EU Member States in the negotiations conducted under the OSCE patronage which concerned Minsk I and Minsk II - peace agreements eventually signed in Minsk. The German involvement in the Normandy Format, which aims at reaching a political solution to the conflict in eastern Ukraine, was perceived with great reserve by the representatives of Polish authorities, i.a. due to turning Poland away from the negotiations. Polish journalists put forward a thesis that the Minsk agreements were a success of Russia and the pro-Russian Ukrainian separatist groups as well as a failure of the postMaidan Ukrainian authorities. The dominant attitude in Poland was intransigence toward Russia, so every compromise was viewed as a failure of the West and Russia's success. While German diplomacy consistently strove for the de-escalation of the conflict in eastern Ukraine, Poland undertook no such initiative. Throughout many years, Poland had aspired to the role of the main creator of the EU's Eastern policy, including the role of Ukraine's defender, but it lost that position to Germany in the years $2014-2015$.

2. The stances of Poland and Germany on Ukraine's EU membership. In 2014, the new, post-Maidan Ukrainian authorities signed a Ukraine-European Union Association Agreement in two stages. Representatives of the Polish government saw that as an incredibly important stage on Ukraine's way to become an EU Member State. However, representatives of the German government accepted and supported Ukraine's European aspirations but did not mention its EU membership. Poland advocated defining a clear-cut deadline for Ukraine's membership by the EU itself, whereas German politicians avoided making such declarations.

3. The stances of Poland and Germany on Ukraine's NATO membership. The conflict in eastern Ukraine greatly distanced that country from NATO membership. A vast majority of the ruling groups in the NATO Member States demonstrated no political will to become entangled in an armed con- 
flict with Russia by supporting Ukraine's aspirations to join NATO. While the stance advocating the need for the Finlandisation of Ukraine (so that the country would remain outside military organisations) was strengthening in the West ${ }^{72}$ the Presidents of Poland, Bronisław Komorowski and Andrzej Duda, as well as representatives of subsequent Polish governments declared their support for the effort made by the Ukrainian authorities to join NATO. At the same time, representatives of the FRG government were definitely against admitting Ukraine to NATO ${ }^{73}$

4. The stances of Poland and Germany on the sense of a military hazard posed by Russia and on strengthening the eastern flank of NATO. Even though negative attitudes toward Russia significantly increased among Germans in the years 2014-2019, German politicians did not acknowledge the Russian hazard toward their country to the same extent as did Polish politicians. It was relatively frequently remarked in Poland that the German stance on the Russian hazard toward Poland and other countries of the Central and Eastern Europe was ambiguous to a certain degree. On the one hand, German politicians undertook actions allowing for the eastern flank of NATO to be strengthened (e.g. Germany's consent to take the command of a rotational battalion in Lithuania in which the Bundeswehr soldiers also participate). On the other hand, the German government did not agree to permanent presence of NATO forces in Poland or the Baltic states (which was sought by the Polish government) i.a. to ensure adherence to the NATO-Russia Founding Act of 27 May 1997, in which the NATO Member States had obliged not to distribute nuclear weapons or considerable armed forces in the new Member States. Unlike German authorities, Polish authorities believed that the Act was no longer in force because Russia had breached it by incorporating Crimea. A dozen days before the NATO Warsaw Summit (8-9 July 2016), German Minister of Foreign Affairs Frank-Walter Steinmeier criticised the NATO Anaconda-16 military exercise held in Poland. He warned that the policy toward Russia should not be limited to military deterrence and "sabrerattling". Those ambiguities in the FRG security policy stemmed from the

${ }^{72}$ Even Zbigniew Brzeziński, an avowed supporter of including Ukraine in the European structures, proposed the Finnish model for Ukraine in 2014, according to which the country would maintain broad economic relations both with Russia and the EU but would not participate in military alliances. Henry Kissinger had a similar opinion on those matters. Z. BRZEZIŃSKI: Fiński model dla Ukrainy. "Gazeta Wyborcza", 25 February 2014; Interview with Henry Kissinger. Do We Achieve World Order Through Chaos or Insight? - www. spiegel.de/international/world/interview-with-henry-kissinger-on-state-of-global-politicsa-1002073.htm1 (accessed: 18.11.2014).

Steinmeier gegen Nato-Mitgliedchaft der Ukraine - www.spiegel.de/politik/deutschland/ukraine-krise-steinmeier-gegen-nato-mitgliedchaft-der-ukraine-a-10004525.htm (accessed: 24.11.2014). 
Deterrence and Dialogue strategy adopted by A. Merkel's government, which assumed ally solidarity with all the NATO Member States and diminishing the tension in the NATO-Russia relations. ${ }^{74}$

5. The stances of Poland and Germany on the prospects for their relations with Russia. Poland froze its relations with Russia on the highest level in the years 2014-2019. During the crisis and conflict in eastern Ukraine, Poland's role as one of Russia's main antagonists in the EU and NATO was strengthened. The decision makers of the Polish foreign policy demonstrated an uncompromising attitude toward Russia, especially in the years 2014-2015. At the same time, Germany conducted a constant albeit difficult dialogue with Russia. Chancellor A. Merkel frequently criticised President V. Putin's policy toward Ukraine, but she still underlined that Russia was and would remain a part of Europe and the EU's biggest neighbour, so a situation where Russia became an enemy of the West instead of its partner was inadmissible. The FRG government still wished to act as a mediator and agent between the West and Russia. ${ }^{75}$ The White Book presented in July 2016 contained not only the criticism of Russia's actions which breached the principles of independence and respect for borders, but also i.a. a statement that NATO's long-term objective concerning Russia was strategic partnership. ${ }^{76}$ A survey conducted by the Friedrich Ebert Foundation at the beginning of 2019 showed that the Russian hazard was perceived by $77 \%$ of Poles and approx. 30\% of Germans. However, $50 \%$ of the surveyed Germans saw the main hazard in the policy conducted by D. Trump..$^{77}$

6. The stances of Poland and Germany on the refugee and migration crisis in the EU. The refugee and migration crisis, which reached its climax in 2015, was seen as the most serious hazard to EU existence and cohesion as well as the greatest challenge for its future. Poland and many other EU Member States strongly criticised the decision made by Chancellor A. Merkel on 24 August 2015 that Germany would consider asylum applications without observing the Dublin procedure in force in the EU at that time and was ready to admit all immigrants (the hospitality policy). Though Chancellor Merkel assured the EU that Germany would handle the inflow of so many refugees, it very quickly turned out that the country was not able to admit all of them

74 K. Szubart: Stanowisko Niemiec na szczyt NATO w Warszawie. Dialog i odstraszanie. "Biuletyn Instytutu Zachodniego" 2016, nr 248; IDEM: Szczyt NATO w Warszawie konsekwencje dla Niemiec. "Biuletyn Instytutu Zachodniego" 2016, nr 260.

75 See M. Stolarczyк: Polska i Niemcy wobec kryzysu i konfliktu ukraińskiego...

76 Das Weissbuch zur Sicherheitspolitik und zur Zukunft der Bundeshwer. Berlin 2016 https://www.bmvg.de/portal/a/bmvg/!ut/p/c4/04_SB8K8xLLM9MSSzPy8xBz9CyrpHK9p NyydL3y1Mz14QTS5A (accessed: 12.11.2016).

Sondaż FES. Niemcy widza zagrożenie w USA, Polacy - w Rosji - https://wiadomosci.wp.pl/sondaz-fes-niemcy-widza-zagrozenie-w-usa-polacy-w-rosji (accessed: 17.02.2019). 
(approx. one million in 2015) in such a short time without truly serious problems. The criticism was even greater, also in Poland, when the FRG government undertook actions aiming at introducing an automatic distribution of immigrants in the EU Member States. In subsequent years, the tendency against immigrant admission strengthened in Poland and other EU Member States, including the FRG. That concerned first and foremost economic migrants due to various implications, including related hazards (e.g. economic, social, security-related and civilisational ones). ${ }^{78}$

7. The difference of Poland's and Germany's interests in their energy and climate policy. In recent years, many people have expressed an opinion that the biggest and long-standing problem in the Polish-German relations is the energy sphere, including the consequences of Germany's Energiewende (energy transition) to the EU's energy and climate policy. ${ }^{79}$ The differences between the Polish and German stances concerning the energy and climate policy stemmed i.a. from the two countries' divergent strategies in this field. In the spring of 2011, after the breakdown of the Japanese nuclear power plant in Fukushima, the FRG government decided to take a turn in the energy policy. Consequently, nuclear power is planned to be eliminated till 2022 (which does not seem realistic), while renewable sources of energy are to supply $60 \%$ of energy by 2050 . The strategy pursued by subsequent Polish governments was just the opposite: it assumed that the Polish energy industry would still be based on hard and brown coal, with an increasing share of nuclear energy in the future. ${ }^{80}$ In principle, Poland and Germany implemented two different models of the national energy policy. Germany aimed at strengthening its energy security, so it cooperated more closely with Russia on the import of Russian energy resources. In the middle of the second decade of the 21st century, Russia was the biggest supplier of gas and crude oil to German economy: approx. $44 \%$ of its gas import and over $30 \%$ of the crude oil import came from Russia. It was anticipated that Russian supplies of gas and crude oil to Germany would increase in subsequent years. Consequently, the dependence of German economy on Russian energy carriers would grow as well. Nord Stream II project implementation will probably be the most evident manifestation of this. In general, instead of reducing the dependence of German economy on Russian gas and crude oil supplies, the FRG ruling groups believed that Germany's energy security would im-

78 See M. Stolarczyk: Stanowisko Polski wobec kryzysu migracyjno-uchodźczego Unii Europejskiej. "Krakowskie Studia Międzynarodowe" 2017, nr 2 (XIV).

79 Polska-Niemcy. Partnerstwo dla Europy? Interesy, opinie elit, perspektywy. Red. P. Buras. Warszawa 2013, p. 48 and subs. pages.

${ }^{80}$ B. Molo: Polska wobec polityki energetyczno-klimatycznej UE $w$ drugiej dekadzie XXI w. "Krakowskie Studia Międzynarodowe" 2013, nr 4 (X); P. Buras: Polska-Niemcy: Partnerstwo dla Europy? Interesy, opinie elit, perspektywy. Warszawa 2013. 
prove if the cooperation with Russia in this scope became closer. At the same time, the decision makers of the Polish foreign policy implemented a strategy aimed at a significant reduction of the dependence of Polish economy on the supplies of Russian crude oil and in particular Russian gas for security reasons and then at achieving complete independence in this scope. Each party expected greater solidarity from the other. Poland expected greater solidarity from Germany in the energy policy and reducing the dependence on Russian energy carriers as well as strengthening the eastern flank of NATO. Germany expected greater solidarity from Poland mainly in tackling the refugee and migration crisis. Striving to block the implementation of Nord Stream II, Polish diplomacy supported the American projects which postulated imposing sanctions on the companies building the second line of the gas pipeline running along the bottom of the Baltic Sea, and that irritated German politicians.

8. The difference of stances concerning the scope of the influence exerted by the historical burden on the interstate and intersocial Polish-German relations. The historical policies in Poland and Germany in the post-Cold War period demonstrated significant differences, the intensity of which varied throughout the years. The historical burden, including disputes over the interpretation of history (first and foremost in relation to World War II and the first years after its end), concerned i.a. the following issues:

- too frequent highlighting by Germany of the consequences of World War II to Germans (e.g. displacements) and their country without taking into account the causes, the first of which was the invasion of Poland by the German Reich on 1 September 1939;

- the process of passing from "the nation of perpetrators" and the feeling of guilt for the crimes of the German Reich to "the nation of victims". This process continues in Germany and aims to demonstrate the "lawlessness" and "harm" of the displacements imposed by the 1945 Potsdam conference arrangements;

- maintaining the German legal doctrine in its present form which questions the validity of the Potsdam Agreement as an act of international law and highlights the lawlessness of displacing Germans from the former eastern regions of the German Reich after World War II and the illegality of German estate expropriations;

- the tendency present in Germany to make the suffering of the German nation toward the end of World War II and afterwards equal to the suffering of other nations which had become victims of German invasion and genocide;

- the lack of political will demonstrated by the subsequent ruling groups of reunified Germany to finally close the issue of the property claims laid by German citizens (displaced people and their descendants) against Poland 
in the Polish-German relations via settling the individual compensation claims by the German state itself $f^{81}$;

- the postulates occasionally put forward in Poland which concern obtaining war reparations from Germany as a financial compensation for the human and material losses suffered by Polish citizens and Polish economy during the German invasion of Poland and its subsequent long-term occupation.

Beside the above, the significant differences between the stances of Poland and Germany in recent years concerned the issues related to the EU integration model and the degree of support for the policy conducted by the administration of Donald Trump. Regarding the further integration process of the European Union, the government led by Chancellor A. Merkel advocated its deepening, including integration strengthening in the field of defence. Subsequent Polish governments after 2015 supported the intergovernmental (confederational) integration model and renationalisation of the EU integration process. Interestingly, by striving to weaken European integration, the decision makers of the Polish foreign policy came closer not only to the policy of D. Trump, who criticised EU integration, but also to the policy of Russia's President V. Putin, who was interested in EU weakening as well.

In the context of the EU and NATO weakening policy pursued by D. Trump and the increasing discrepancies in transatlantic relations, German politicians said that Europe was no longer able to rely on the USA utterly and had to take its fate in its own hands. In August 2018, German Minister of Foreign Affairs Heiko Maas said that the EU and Germany needed to build a counterbalance to the USA and create an alliance for multilateralism. ${ }^{82}$ At the same time, Poland's security policy focused on strengthening the bilateral relations with the USA ${ }^{83}$ even though President D. Trump demonstrated a business-like approach to ally

${ }^{81}$ See more in M. Stolarczyк: Dylematy polityki niemieckiej Polski zwiazane z zakresem wpływu obciażeń historycznych na międzypaństwowe stosunki polsko-niemieckie. W: Bezpieczeństwo międzynarodowe Polska -Europa - Świat. Księga Jubileuszowa dedykowana Profesorowi Ryszardowi Ziębie z okazji czterdziestolecia pracy naukowej. Red. J. Zając, A. WŁodKowska-Bagan, M. Kaczmarski. Warszawa 2015.

${ }^{82}$ Minister H. Maas supported a balanced partnership between Europe and the USA. In his opinion, the EU should become strong enough to be capable of opposing America on the agreement with Iran or the trade balance; in other words, it should create a counterbalance wherever the USA crossed the red line - https://www.dw.com/pl/szef-msz-niemiec-czas-nanowa-wizje-partnerstwa-europy-z-usa/a- (accessed: 12.10.2018).

George Friedman, an American political scientist and founder of the Stratfor platform, said in one of his interviews that, from that moment on, America was going to defend only those European countries which were important to its own interest. "We want to stop Russia. Poland and Romania are indispensable for that, but it is no longer about NATO. It is about bilateral arrangements." Europa niebezpieczna sama dla siebie. Wywiad z George'em Friedmanem. "Rzeczpospolita", 1-2 September 2018. 
obligations. According to certain opinions, also in the Polish press, Poland reduced itself to the role of the USA's vassal. As the controversy concerning the USA - EU relations (especially the USA - Germany relations) increased, one of the main dilemmas in the Polish foreign policy was whether Poland should support the USA or the EU (Germany) in that dispute. Good relations with both countries are in Poland's interests.

\section{Main stages of Poland's relations with the Russian Federation in the post-Cold War period and their characteristics}

Poland's policy toward the Russian Federation in the years 1992-2018 can be divided into seven stages:

Stage one: building the foundations based on a treaty (1992 - 1993). At this stage, Poland regained full independence in its relations with the Russian Federation, the strongest manifestation of which was the withdrawal of the last troops of the former Soviet army stationing in Poland (1993) as well as the adoption of new formal and legal regulations as the basis for a new stage of the PolishRussian relations in this scope. The most important agreement in this field was the Treaty between the Republic of Poland and the Russian Federation on Good Neighbourhood and Friendly Cooperation, signed on 22 May $1992 .{ }^{84}$ Although the treaty did not resolve many disputable issues, it opened the door to the normalisation of the Polish-Russian relations and broad cooperation ${ }^{85}$;

Stage two: the Polish-Russian relations in the shadow of the first post-Cold War NATO enlargement (1993 - 1999). The Polish-Russian relations at that time were determined not only by historical issues, but first and foremost by Poland's aspirations to join NATO and the negative impact of the first NATO enlargement, in which Poland took part, on Russia's security according to an assessment carried out by the Russian ruling groups (a deterioration of Russia's geostrategic location). To many politicians and journalists as well as other opinion-forming groups in Poland, the main yet not declared reason for Poland's membership in NATO was the sense of a hazard posed by Russia. Krzysztof Fedorowicz wrote that the majority of Polish society viewed Russia as a continuation of the USSR,

${ }^{84}$ See the text of the treaty in J. Kunulka: Traktaty sasiedzkie Polski odrodzonej. Wrocław 1998, p. 226-231.

85 The disputable issues not regulated by the treaty signed on 22 May 1992 included i.a. compensation for the victims of Stalinist crimes (which Russia refused to include in the treaty) and a full explanation of the Katyn massacre, the rehabilitation of its victims and compensation for their families. 
with all relevant consequences (also historical ones) included. ${ }^{86}$ Therefore, the Polish political elite demonstrated far-reaching scepticism concerning the need for building a European security system together with Russia. Russia's objection to NATO enlargement was commonly viewed in Poland as one of the most important examples confirming the rightness of the thesis dominating the Polish political discourse, according to which Polish security was indeed threatened by Russia as that country wanted to regain its influence in Poland and the objection constituted a manifestation of its imperial policy;

Stage three: the Polish-Russian relations in the context of finalising Poland's effort to become a Member State of the European Union (1999-2004), the second NATO enlargement in the post-Cold War period in 2004 (admission of i.a. Lithuania, Latvia and Estonia) and the effort made by the decision makers of the Polish security policy to strengthen the bilateral relations with the USA, first and foremost in politics and security. One manifestation of that was the utter support of the Polish ruling groups for the foreign policy conducted by the administration of President George W. Bush and the effort to show ally loyalty to the USA (e.g. via the participation of Polish soldiers in the 2003 American invasion of Iraq at the side of US soldiers) as well as the striving of Polish politicians for the elements of the American Ballistic Missile Defence to be distributed in Poland. Contrary to certain forecasts, Poland's admission to NATO did not result in better PolishRussian relations ${ }^{87}$ Just the opposite: the NATO membership and the resulting increased sense of security encouraged a part of the Polish political circles to conduct a more resolute policy toward Russia. Poland's support for the NATO military intervention in Serbia (1999), for the resulting change of NATO from a defensive alliance to a defensive-offensive alliance and for the most controversial actions taken by the administration of President G.W. Bush in the international policy together with Russia's objection to those actions constituted a significant burden to the Polish-Russian relations as well. However, despite the numerous disputable issues in the Polish-Russian relations, both parties undertook actions in the discussed period in order to strengthen the normalisation process of those relations. A very important event on that way was the official opening of the Polish military cemeteries in Katyn (28 July 2000) and Mednoye (2 September 2000), with Poland's Prime Minister Jerzy Buzek and representatives of the Rus-

${ }^{86}$ K. Fedorowicz: Polityka Polski wobec Rosji, Ukrainy i Białorusi w latach 19892010. Poznań 2011, p. 99.

${ }^{87}$ Friedbert Pflüger, a member of the CDU/CSU fraction in the Bundestag, wrote that Poland's NATO membership was not an obstacle to Polish-Russian reconciliation but its prerequisite because only those who felt safe were able to maintain the bonds of partnership and develop cooperation. E. PflüGER: Warunek pojednania Polski z Rosja. "Dialog" 1998, nr 2, p. 104. According to Z. Brzeziński, the Eastern enlargement of NATO in 1999 liquidated the area of strategic emptiness between Russia on one side and Germany and Western Europe on the other, thus offering real possibilities of a slow yet consistent Polish-Russian reconciliation. Wschodni filar. Rozmowa ze Zbigniewem Brzezińskim. "Polityka" 1999, nr 11. 
sian government participating in the ceremonies. The period of 2001-2002 in the Polish-Russian relations also saw a mutual intensification of political visits on the highest level, including a visit of President Vladimir Putin to Poland (16-17 January 2002) and a visit of President Aleksander Kwaśniewski to Russia (6 June 2002). When Poland joined the EU on 1 May 2004, one of the most important motives behind its actions within the EU's Eastern dimension was the striving to accelerate the Westernisation of Ukraine, Belarus and Moldova as part of the EU policy and weaken Russia's influence in those countries, which strengthened the differences between Poland's and Russia's strategic interests in their policies toward Eastern European countries. A very meaningful example of that was the involvement of Polish politicians in the Orange Revolution in Ukraine at the turn of 2004 and 2005 and their support for one of the sides (Russia's adversaries) fighting for power in that country as well as the definitely negative assessments of that involvement in Russia.

Stage four: an escalation of tension and an intensification of negative emotions in the Polish-Russian relations during the implementation of a political project called the Fourth Republic of Poland [IV RP] by the PiS government (20052007). That stage was predominantly related to the implications of the Polish politicians' involvement in the Orange Revolution in Ukraine at the end of 2004 and the tough policy toward Russia and Germany conducted by the government formed by PiS and its coalition partners in the years 2005-2007. The PiS government put forward a thesis that Poland's interest in its relations with Russia and Germany had to be pursued in a better way than before 2005. In the middle of the first decade of the 21st century, the competition for the direction of Ukraine's transformation became one of the fundamental tension-inducing issues in the Polish-Russian relations. Besides, Poland's policy toward Russia saw an increase of controversy in connection i.a. with: the historical burden stemming from the different historical memories of Poles and Russians; disputes over the agreement of September 2005 on the building of a German-Russian gas pipeline along the bottom of the Baltic Sea, signed by German and Russian concerns; the effort made by the PiS government and President Lech Kaczyński for the elements of the American Ballistic Missile Defence to be distributed in Poland; Poland's support for the idea of another Eastern enlargement of NATO to include Ukraine and Georgia; and disputes over Russia's decision concerning the introduction of a temporary ban on importing Polish meat. It should be underlined that the decision makers of the Polish security policy at that time highlighted the Russian hazard to Poland's independence predominantly in the area of energy security, while the military hazard was mentioned less often. Both the theory and practice of the Eastern policy conducted by PiS was clearly marked with the attachment of its politicians to the Intermarium project.

Stage five: attempts to make Poland's policy toward Russia more pragmatic in the first years of the government formed by the PO/PSL coalition (2008-2010). 
That stage entailed new elements in Poland's Eastern policy pursued by the $\mathrm{PO} /$ PSL government. The new decision makers of the Polish foreign policy, led by Prime Minister Donald Tusk, declared their will to improve the relations with Russia and their government implemented a more realistic and pragmatic Eastern policy which was simultaneously less ideological. The PO/PSL government representatives expressed their willingness to conduct the dialogue with Russia while accepting that country as it was ${ }^{88}$ They simultaneously stressed that Poland had justified aspirations to co-shape the EU's Eastern dimension and support Ukraine's pro-Western ambitions. ${ }^{89}$ Such was the objective i.a. of the Polish-Swedish Eastern Partnership project, ${ }^{90}$ submitted in 2008 and approved in March 2009 by the European Council as an EU proposal. Russia viewed Eastern Partnership as another manifestation of Poland's anti-Russian actions, that time within the EU, and as a project aimed at pushing the included countries away from Russia and broadening the EU's zone of influence at Russia's cost. The Polish effort aimed at adopting a declaration promising Ukraine and Georgia NATO membership quickly, which was supposed to be passed by the NATO Member States at the NATO Bucharest Summit (2-4 April 2008), was criticised even more in Russia. ${ }^{91}$ The Russian-Georgian conflict concerning South Ossetia in August 2008 led to a significant temporary deterioration of the Polish-Russian relations. It also accelerated the works on the signing of the Polish-American agreement on the Ballistic Missile Defence (20 August 2008). Russia saw the installation of the American Ballistic Missile Defence elements in the territory of Poland as a deterioration of its own geostrategic situation via a considerable weakening of the deterring power possessed by Russian nuclear weapons. ${ }^{92}$

On 10 April 2010, 96 people died at a plane crash near Smolensk. They included President of Poland Lech Kaczyński and his wife, representatives of all the Polish parties present in the parliament and Polish Army commanders, who were going to a celebration commemorating the Katyn massacre victims on the 70th anniversary of that event. The Smolensk disaster, and in particular

88 Presentation of the action plan for the Council of Ministers by Prime Minister Donald Tusk with a motion for a vote of confidence, 23 November 2007 — www.rp.pl/artykul71439. html?p=33 (accessed: 11.03.2014).

Ibidem.

90 The program included Ukraine, Moldova, Georgia, Armenia and Azerbaijan; it also allowed for an inclusion of Belarus.

91 Poland's efforts to include such a provision in the NATO Summit final declaration eventually failed i.a. due to Germany's objection to NATO's assuming that obligation toward Ukraine.

92 On 17 September 2009, President B. Obama informed Poland that his administration was going to withdraw from building the Ballistic Missile Defence version proposed by the administration of G.W. Bush. Still, it meant a modification of the system rather than giving up its construction entirely. 
the diverse opinions on its causes, strengthened the divisions in Polish society as well as the attitudes of aversion and hostility toward Russia. A significant part of the Polish political circles and Polish society was unable or unwilling to accept the version which suggested an unplanned air disaster (aviation accident) as the cause of death of the Polish president and those accompanying him, the source of which was the failure to observe relevant procedures both by Poland and Russia. As time went by, an increasing number of Poles supported a view that the disaster had been caused by an attempt on the lives of the Polish delegation members made by Russia's authorities and secret service. The conclusion, highlighted especially by PiS politicians, was that Poland should take actions aimed at the weakening and isolation of Russia as well as minimising the cooperation with that country instead of making it closer.

Stage six: a deadlock in the Polish-Russian relations in the years 2011-2013, caused predominantly by internal disputes in Poland over the nature of its policy toward Russia after the disaster of the Polish President's plane near Smolensk as well as Polish-Russian disputes over the disaster causes, Poland's reservations about the relevant investigation conducted in Russia and Russia's refusal to return the wreck of the plane in question. Following the Smolensk disaster, the issues concerning the nature of Poland's policy toward Russia and the PolishRussian relations became one of the most important areas of political fight in Poland. The ruling coalition and the main opposition parties as well as the circles that supported them demonstrated considerable differences in the perception of the Polish national interests in the relations with Russia as well as the manners of their accomplishment. The government led by Prime Minister D. Tusk did not manage to prevent the incredibly emotional internal discussion on the causes and consequences of the Smolensk disaster from causing the stagnation of the Polish-Russian political relations, which progressed especially from the middle of 2011 and gradually paralysed those relations. The policy of the PO/ PSL government toward Russia was largely conducted under the pressure of the right-wing opposition parties and became increasingly similar to the policy proposed by the leaders of PiS.

Stage seven, which began at the end of 2013. The Polish-Russian relations in subsequent years were nearly completely determined by the Ukrainian crisis, Crimea incorporation by Russia, the conflict in eastern Ukraine as well as the political and economic sanctions imposed on Russia by the West. When listening to numerous Polish politicians, journalists and analysts of international affairs, especially in the years 2014-2015, one was able to conclude that the Russian army was preparing for an invasion of Poland. ${ }^{93}$ Any rational, objec-

93 Generat Stanistaw Koziej nie wyklucza inwazji Rosji na Polske — http://wiado mosci.wp.pl/kat,1342,title,General-Stanislaw-Koziej-nie-wyklucza-inwazji-Rosji-na-Pols ke,wid,17272158,wiadomosc.htm1 (accessed: 6.03.2015). 
tive or simply common-sense analysis of the reality was suppressed by negative emotions. The media were permeated with anti-Russian war hysteria and voices advocating resolute actions against Russia. Fairly few people in Poland at that time reckoned that there were no reasons why Russia could be willing to pose a military hazard to Poland or other Central European NATO Member States. ${ }^{94}$ A similarly small group of people believed that the main hazard to Poland's security was not a military hazard posed by Russia, but Poland's own internal tendency to confront Russia..$^{95}$

Poland and the USA were the Western countries which advocated imposing the most severe sanctions possible on Russia. In 2014 and subsequent years (till the middle of 2019, when this article was being finalised), Poland froze its political relations with Russia on the highest level. Polish politicians underlined that it would only be possible to resume the normalisation of the relations with Russia after solving the Russian-Ukrainian conflict in eastern Ukraine. However, they did not explain precisely what they meant by "solving the Ukrainian conflict." Did they expect full implementation of the Minsk II peace agreement provisions or, in addition, returning Crimea to Ukraine, which seems unlikely? The conflict in eastern Ukraine set a new turning point in the Polish security policy and the Polish-Russian relations. Polish authorities officially started to treat Russia as the main hazard to Polish and international security, including a military hazard in the form of a direct invasion. ${ }^{96}$

Beside Crimea incorporation by Russia and the conflict in eastern Ukraine, the important disputable issues in the Polish-Russian relations at that time included: historical matters, including the disassembly in Poland of the monuments commemorating the Soviet soldiers who fell in the territory of Poland during the fights with the German Reich; construction of the Ballistic Missile Defence elements in Poland by the USA; and the Smolensk disaster, ${ }^{97}$ including Russia's refusal to return the wreck of the Tu-154M plane to Poland. ${ }^{98}$ In general, neither Poland nor Russia showed any political will to improve their mutual relations in the years 2014 - 2018. Instead, either party blamed the other for the freezing of political contacts and expected it to resume the effort to improve them.

${ }^{94}$ See more in: M. Stolarczyк: Rosja w polityce zagranicznej Polski...

95 A. ŚLiwiński: Non possumus! "Polityka Polska" 2015, nr 1, p. 159-160.

${ }^{96}$ See more in: M. StolarczyK: Rosja w polityce zagranicznej Polski...

${ }^{7}$ On 27 March 2015, Polish Chief Military Prosecutor's Office announced that the Polish President's plane crew was the main party to blame for the Smolensk disaster.

98 The Russian authorities argued that the plane remnants constituted evidence in the Smolensk disaster investigation going on in Russia and that their return to Poland would only be possible after concluding that investigation. 


\section{Main areas of divergent interests in Poland's relations with Russia in the second decade of the 21st century}

Although the Polish-Russian relations in the post-Cold War period underwent many stages, each of which was specific in its own way, they featured predominantly continuous elements. The key one was the great divergence of interests between Poland and Russia. The main disputable issues in the PolishRussian relations in the second decade of the 21 st century as well as in the earlier years were as follows:

1. The European security system, including the role of NATO in its shaping and the subsequent NATO enlargement phases, especially those admitting the post-Soviet countries. Poland and many other NATO Member States supported a thesis that the core of the international security system in post-Cold War Europe should be the North Atlantic Alliance, including the USA's military presence in Europe. Representatives of Russia's authorities did not share that opinion, especially after NATO's aggression against Serbia in 1999. Moreover, Russian politicians frequently argued that NATO was a Cold War relic and the security system in post-Cold War Europe should be built with Russia's participation. After obtaining NATO membership, Poland became one of its Member States which consistently and most resolutely advocated an admission of the Baltic states and other post-Soviet states, first of all Ukraine and Georgia, to the alliance. Russia assessed those actions as very unfavourable to its security interests in the area of its neighbours, believing that NATO was trying to encircle it. The Russian authorities reckoned that Poland's actions were those of a contractor executing the USA's policy toward the post-Soviet region.

It seems that in the 1990s, when the USA's international position as the only superpower kept growing, while Russia's position was weakening as it was struggling with a crisis, the world wasted the chance to build a cooperative European security system with Russia's participation. In the middle of the 1990s, American politics was conquered by an option which assumed the maximum geopolitical use of Russia's economic, political and military weakness and an increase of the USA's influence in the post-Soviet region. It was one of the reasons why the chance to build a cooperative European security system with Russia's participation became increasingly distant in the subsequent decades of the postCold War period.

2. The energy security system and Poland's effort to diversify its energy resource supplies as well as Russia's actions aimed at diversifying its gas and crude oil transfer routes to Western Europe via bypassing the territories of Ukraine and Poland. Even though the dependence of 
Polish economy on the import of Russian gas was much smaller than that of many other EU Member States, Poland put the strongest emphasis of them all on the hazard to the EU's energy security stemming from excessive dependence on Russian gas supplies. ${ }^{99}$ It also seems that the Polish ruling groups too often equated the Polish and Ukrainian energy security interests in the Polish energy policy in connection with Russian gas supplies, sometimes supporting Ukraine's interest more than Poland's interest ${ }^{100}$;

3. The historical dispute, in which Poland particularly underlined the need for a comprehensive explanation of the Katyn massacre and some form of compensation satisfying the Polish party, granted to the families of the persons murdered in Katyn and other locations in the former USSR. The historical memories of Poles and Russians were extremely different for many matters and no mutual interpretation of numerous historical events or processes will probably be developed in the future, either (e.g. the assessment of USSR policy toward Poles during World War II and after its end; the scope of settling accounts with the Stalinist past in Russia; or the nature of the historical policies conducted by subsequent Polish and Russian governments in the post-Cold War period). One must realise that disputes over the interpretation of history may last not only many years, but also many decades. However, the anti-Russian attitudes of a significant part of Polish society were to a very large extent maintained or virtually strengthened by certain right-wing Polish political parties and the Polish journalist environment, the majority of which supported those parties. Both groups made the policy of "intransigence toward Russia" one of the most important elements of their political identity as well as one of the most significant means of mobilising their electorate. ${ }^{101}$

${ }_{99}$ Kamila Pronińska writes, "However, contrary to most EU Member States, where the import dependence itself is seen as the main problem, Poland is first and foremost worried about the dependence on a country which posed a hazard to its existence and sovereignty. The significance of historical resentments in the Polish-Russian relations seems to be crucial in the shaping of Polish perception of energy security". K. PronińsKa: Strategie bezpieczeństwa energetycznego państwa na przykładzie wybranych krajów UE. W: Państwo $w$ teorii i praktyce stosunków międzynarodowych. Red. M. Sulek, J. Symonides. Warszawa 2009 , p. 284.

100 For example, in the 1990s, when Russia made Poland offers to become the main transfer country for the Russian gas supplies sent to the West, subsequent Polish governments did not agree to the bypassing of Ukraine for the sake of political solidarity with that country. Consequently, it is justified to ask: If the Polish ruling groups had made a different decision at that time, would the gas pipeline running along the bottom of the Baltic Sea and bypassing Poland have been built at all?

${ }^{101}$ See more on this topic in M. StolarczyK: Prawicowy populizm w Polsce jako jedna z barier na drodze do poprawy stosunków polsko-rosyjskich. "Krakowskie Studia Międzynarodowe" 2011, nr 4. 


\section{The contradictory visions of building an order in Eastern Europe, first of} all in Ukraine (a geopolitical conflict of interest concerning the shape of the Eastern European order). As time went by, especially after Poland had joined NATO and the EU, the future of Eastern European countries, especially Ukraine and Belarus, became an issue of fundamental importance to the Polish-Russian relations. Both Russia and Poland treated Eastern European countries as a certain security buffer separating the Western security zone built under US leadership from the security zone built by Russia in the postSoviet region. However, the two countries' visions of the shape of that buffer were fundamentally different. The Polish ruling groups believed that the improvement of Poland's security required strengthening of the Ukrainian buffer via admitting the latter country to NATO and the EU. On the contrary, the Russian ruling groups reckoned that the Ukrainian buffer would strengthen Russia's security if Ukraine obtained the non-aligned status or was included in the security system built under the aegis of Russia in the CIS area.

The dominant stance in Poland stated that the relations with Russia were very difficult, but it was not Poland's fault. The Russian party was the only one blamed for the freezing of the Polish-Russian political relations. It is hard to agree with that stance because subsequent Polish governments expected that Russian authorities would nearly fully acknowledge the Polish stance on national and international security, but they showed no understanding of the Russian interests in that scope themselves. I agree with the opinion that Poland will find it hard to conduct an effective foreign policy in the East and the West without taking into account at least a part of Russia's interests concerning security and other matters. ${ }^{102}$ Adam Daniel Rotfeld justifiably argues that diplomacy is the search for a balance of interests and the manner of reaching a compromise with mutual respect. ${ }^{103}$ The problem is that the decision makers of the Polish foreign policy too often viewed any compromise in the relations with Russia virtually as a betrayal of Polish interests.

\section{Similarities and differences in Poland's policies toward Germany and Russia in the post-Cold War period}

Germany was Poland's main economic partner in Europe and worldwide from the beginning of the 1990s till the end of the second decade of the 21st cen-

102 S. Bieleń: Polska między Niemcami a Rosja — determinizm czy pluralizm geopolityczny? W: Polityka zagraniczna Polski po wstapieniu do NATO i do Unii Europejskiej. Problemy tożsamości i adaptacji. Red. S. Bieleń. Warszawa 2010, p. 270.

103 A.D. RotFeld: W poszukiwaniu strategii. Olszanica 2018, p. 103. 
tury. Germany's share in Polish trade reached nearly 30\% in 1991 and approx. $25 \%$ in 2017 (27.4\% in the export and 23\% in the import). In 2017, the PolishGerman trade value significantly exceeded 100 billion EUR. In the same year, Russia took the third place in Polish import (13.2 billion EUR) and the seventh place in Polish export (6.2 billion EUR). Therefore, the Polish-Russian trade value reached less than 20 billion EUR. Nonetheless, it must be mentioned that, despite the still binding economic sanctions imposed on Russia in the middle of 2014 and Russia's counter-sanctions imposed on the West, including Poland, as well as the drop of the Russian consumers' buying power in recent years, Poland's export to Russia in 2017 increased by $20.1 \%$ and the import increased by as much as $27.7 \%$ in comparison with 2016. It is estimated that Poland has lost approx. three billion EUR since 2014 due to the lower export to Russia. ${ }^{104}$ By way of comparison, despite the officially maintained German sanctions against Russia, German companies increased the export to Russia in 2017 by $20 \%$, reaching 26 billion EUR, while German import from Russia at the same time increased by $18.3 \%$ and reached 31 billion EUR. The total German-Russian trade value in 2017 was 57 billion EUR and was much lower than before the conflict in eastern Ukraine ( 80 billion EUR). As the data show, Russia's share in Poland's trade was much lower than Germany's share. Still, one must remember that Russia was Poland's most important economic partner in the Eastern dimension of the Polish foreign policy in the discussed period..$^{105}$

One of the most characteristic features of the Polish-Russian trade was Poland's very high debit balance (e.g. more than 12 billion USD in 2012), which stemmed from the trade structure and the dominant position of gas and crude oil in Polish import from Russia (approx. 75-80\%). The characteristic features of the Polish-Russian economic relations included their considerable dependence on the nature of the Polish-Russian political relations. Such dependence of the economic dimension on the political one did not occur in the Polish-German relations.

In Poland's policy toward Russia, contrary to its policy toward Germany (especially in the 1990s, when the Polish-German reconciliation process was initiated in the intergovernmental Polish-German relations), there was no political will to make a fundamental breakthrough despite the occasional attempts to improve the mutual relations made by Poland and Russia alike. Even though the Polish-German relations feature numerous disputable issues, the ruling groups of both countries usually showed willingness to solve and ease the appearing problems instead of escalating the disputes. Such will was definitely smaller in

104 https://www.rp.pl/Gospodarka/303189919-Wymiana-handlowa-Rosja-to-niestabilnyrynek (accessed: 1.10. 2018).

In 2016, the estimated value of Polish export to Ukraine was approx. 16 billion PLN, while the import reached approx. 8 billion PLN. Ukraine accounted for $1.9 \%$ of Polish export and $1 \%$ of Polish import — w ww.mapa.kuke.com.pl/ukraina.html (accessed: 4.10.2018). 
the Polish-Russian relations on both sides. ${ }^{106}$ The Polish-Russian relations were much more conflictual than the Polish-German relations. In general, the PolishGerman relations were dominated by the tendency to ensure development and strengthen the cooperation, while the Polish-Russian relations were usually critical in nature. The relations with Russia definitely stirred up more negative emotions in Polish society than did the relations with Germany. One cause of that situation was the fact that the disputable issues in the Polish-Russian relations concerned the strategic interests of both countries to a much larger extent than did the Polish-German relations.

The fear of a German capital inflow gradually decreased in Poland in the subsequent years after the reunification of Germany. On the contrary, the fear of a Russian capital inflow was very strong in Poland in the subsequent decades of the post-Cold War period. Though the scale of Russian investments in Poland was small ${ }^{107}$ in comparison with i.a. the dominating German investments, the attempts at increasing the Russian ones were usually perceived as a hazard to Poland's national security. Subsequent offers made by Russian companies were typically analysed in terms of politics and security, not in terms of business. Poland was worried that Russia might gradually take control of the important branches of Polish economy and therefore influence Polish political life. Examples include preventing Lukoil from the purchase of the Gdańsk Refinery (currently Grupa Lotos) and the Polish government's objection to Viatcheslav Moshe Kantor's attempts at purchasing the Tarnów-based Azoty concern.

In the entire post-Cold War period, Russia was the main point of reference in the Polish decision makers' perception of the Polish national and international security policy. However, that leading role stemmed mainly from viewing that

106 On 17 August 2012, a mutual address was signed by Patriarch Kirill of Moscow and Abp J. Michalik. Still, it is hard to predict the degree to which that call of both Churches for a Polish-Russian reconciliation will translate into the practice of the Polish-Russian relations and make Poles' attitudes toward Russia more positive. One should remember that many years passed from the Pastoral Letter of the Polish Bishops to their German Brothers of 18 November 1965, which featured the statement "We forgive and ask for forgiveness", to the Polish-German reconciliation process, which began after 1989. Contrary to what happened in the Polish-German relations, the reconciliation process in the Polish-Russian relations will be longer and harder. This provokes the following question: How long will it take the Polish and Russian ruling groups to free the current Polish-Russian relations "from their enslavement to history and break the determinism of hostility" the way it has largely been accomplished in the Polish-German relations? See: S. Bieleń: Szanse na pojednanie polsko-rosyjskie $w$ świetle wyzwań geopolitycznych. W: Geopolityka w stosunkach polsko-rosyjskich...

107 In the years 1990-2014, foreign investors spent nearly 600 billion EUR in Poland, less than 2 billion EUR of which were Russian investments. M. RABIJ: Rosyjski kapitat $w$ Polsce? Prawie nieobecny - biznes.newsweek.pl/rosyjskie-inwestycje-w-polsce-newsweek-pl, artykuly,285428,1,html (accessed: 20.05.2014). At the beginning of 2013, only five companies with Russian capital and as many as 389 companies with German capital were registered in Poland. 
country as the main hazard to Poland's security interests, not as a recognised partner in their accomplishment, as in Germany's case. When Poland joined NATO, Poland and Germany became allies. Russia, however, was perceived, albeit with varying intensity, as the main hazard to Poland in the practice of the Polish foreign policy in the subsequent decades of the post-Cold War period. ${ }^{108}$ The fear of Russia and the sense of hazard posed by that country determined Poland's security policy. ${ }^{109}$ That stance matched the history of the 19th- and 20thcentury Polish political thought, in which the main feature of virtually all the Polish political currents was confrontation with Russia, the anti-Russian attitude and the striving to "push Russia away to Asia." ${ }^{110}$. The Polish-German relations in the entire post-Cold War period were definitely better than the Polish-Russian relations, which were usually in crisis. That state was caused not only by Russia, but also subsequent Polish governments, the actions of which often strengthened the sense of a Russian hazard perceived by Polish society.

Due to the leading role of the Russian factor in Poland's security policy, many truly significant actions taken within the most important dimensions of the Polish foreign policy were determined by the sense of a hazard posed by Russia. The areas determined by that factor to the largest extent included Poland's relations with the USA, policy implemented within NATO and numerous actions taken in the EU, especially as part of the EU's Eastern dimension, including Polish policy toward Ukraine. A permanent element of Poland's Eastern policy in the post-Cold War period was the effort to develop the cooperation with Ukraine and other post-Soviet states and integrate them with the West, with a simultaneous effort to isolate Russia and "push" it out of Europe. The consideration for "the Russian factor" was also the leading one among the actual yet not declared reasons why the subsequent Polish governments of the 1990s aimed at NATO membership and the Polish ruling groups in the first and second decade of the 21st century made effort for the elements of the American Ballistic Missile Defence to be installed in Poland. Stanisław Bieleń writes that the circles ruling Poland treated Russia "as a simple continuation of the Soviet Empire - a timeless existential enemy." "111 It seems justified to say in this context that the anti-Russian attitude was a strategic factor in the Polish

108 A relevant survey conducted in Poland in August 2014 showed that nearly 83\% respondents believed Russia's expansive policy was the greatest hazard to Poland's security. In August 2017, 40.1\% respondents shared that opinion. M. Kolanko: Rosja juz nie taka straszna. "Rzeczpospolita", 17 August 2017.

109 See J. Zając: Poland's Security Policy: The West, Russia, and the Changing International Order. London 2016.

110 R. Juchnowski: Miejsce geopolityki w polskiej myśli politycznej..., p. 319 and subs. pages.

111 S. Bieleń: Stosunki Unia Europejska-Rosja. W: Dyplomacja czy siła? Unia Europejska w stosunkach międzynarodowych. Red. S. PARzymies. Warszawa 2009, p. 233. 
politics of the post-Cold War period. ${ }^{112}$ Many Polish politicians and journalists viewed the intensity of the anti-Russian attitude as the main criterion of patriotism. ${ }^{113}$ The Russian factor played a significantly greater role in the shaping of the Polish foreign policy within bi- and multilateral relations than did the German factor.

Poland's policy toward Russia depended on the USA's policy toward Russia much more than did Germany's policy in this scope. A noticeable number of people believed that it was beneficial to the Polish security interests whenever the American-Russian relations worsened because that enhanced Poland's role in the USA's foreign policy and made Poland "a great front line country countering Russia's ambitions in Europe." 114 The German-American relations in the first and second decade of the 21st century featured considerable areas of divergent interests, e.g. those concerning the resolution of the Iraqi, Libyan and Iranian problems. In most of those disputes, except the manner of solving the Libyan problem in 2011, Poland's stance was usually identical or similar to the American stance.

In the subsequent decades of the post-Cold War period, "the German problem" defined as sense of a political, economic and military hazard diminished in Poland, while the significance of "the Russian problem" increased. Poland's policy toward Germany in the last 30 years did feature occasional disputable issues which were sometimes viewed as new manifestations of "the German problem" (e.g. regarding the growth of Germany's role in the EU in recent years), but the significance of "the German problem" 115 in Polish politics was much smaller than that of "the Russian problem". In this context, the crucial factor in Poland's policy toward Russia is the answer to the following question: Was the perception of the Russian hazard by the decision makers of the Polish foreign and security policies as well as in the Polish media in the discussed period adequate to the actual (real) hazard or was that hazard considerably exaggerated? Was that first and foremost a result of treating "the Russian problem" instrumentally too often in the Polish internal and foreign policies? Did history, the cultural and civilisational factors, prejudice and stereotypes exert an excessive influence on Poland's policy toward Russia? One must remember that the coexistence of

112 See: K.B. JANOwski: Polityka wschodnia RP, p. 9 - http://karol-b-jaowski.waw.pl POLITYKA\%20WSCHODNIA\%RP.pdf (accessed: 4.09.2018). See B. ŁAGOWSKI: Polska chora na Rosję. Warszawa 2016.

114 A. Talaga: Chłód na linii USA-Rosja szansa dla Polski. "Rzeczpospolita", 17—18 August 2013.

115 One should remember that "the German problem" was mentioned also in the German political discourse regarding the growth of Germany's international role, mainly within the EU. See Europa und die neue Deutsche Frage. Ein Gespräch mit Jürgen Habermas, Joschka Fischer, Henrich Enderlein und Christian Calliess. "Bläter für deutsche und internationale Politik" 2011, Nr. 5. 
convergent and divergent interests is a permanent element of interstate relations. Their scope does change though, especially from the medium- and long-term perspective. That evolution is determined by the changing internal conditions as well as those present in the international environment. Still, whether the differences of interests in bi- and multilateral relations lead to confrontations or compromises depends first and foremost on the decision makers of the foreign policies pursued by the countries.

One of the most characteristic features of the Polish foreign and security policies in the post-Cold War period was the perception of Russia from the angle of history. ${ }^{116}$ The historical burden (historical memory) in the Polish-Russian relations was much greater than in the Polish-German relations. A discussion on the assessment and comparison of the two greatest totalitarian regimes of the 20th century, Hitlerism and Stalinism, was going on with varying intensity in Poland, Germany, Russia and other countries in the analysed period. As time went by, the tendency to relativise the crimes of German fascism intensified in Germany. The dominant stance in Russia stated that Hitler's rule had been much more criminal than Stalin's. The great revision of the history of World War II and the post-war years which took place in Poland after 1989 strengthened the tendency to "shift the emphasis from Auschwitz to Katyn". An important part of the discussion on German fascism and Soviet Stalinism was the search for an answer to the question about the scope of German and Russian guilt toward Poland and Poles. A conviction that the discussion about guilt should cease belabouring the guilt of Hitlerism and centre around Stalinism gradually strengthened both in Poland and Germany. Even though German occupation claimed a significantly higher number of lives in Polish society than did Soviet occupation, ${ }^{117}$ the tendency to equal German occupation with the Soviet domination after World War II strengthened in Poland after 1989. One should remember here that it was the policy of the German Reich, not of Soviet Russia, that threatened the biological existence of the Polish nation. ${ }^{118}$

116 See more in: Pamięć i polityka historyczna w stosunkach polsko-rosyjskich. Red. S. Bieleń, A. Skrzypek. Warszawa 2017.

117 The Institute of National Remembrance (IPN) estimates that German occupation claimed the lives of 5.470-5.670 million Polish citizens, whereas the Soviet Union killed approx. 150 thousands of Polish citizens from 1939 to the beginning of the 1950s. M. KARNOWSKI: Nowy bilans ofiar II wojny światowej opublikowany przez Instytut Pamięci Narodowej. "Dziennik", 26 August 2009.

118 Ryszard Stemplowski indicates that the Polish-German conflict was extreme in nature, while Poland's conflict with Russia had a more complex structure. "German Nazis, the then Germans, rejected us completely, reckoned that we were subhumans in general and directly threatened our existence, while Russian Communists first and foremost wanted to make Poland resemble Russia by force and threatened mainly our identity." R. SтеMPLOWSKI: Wprowadzenie do analizy polityki zagranicznej RP. Wyd. II. T. 1. Warszawa 2007, p. 121. 
Poland was capable, albeit to a limited extent, of influencing Germany's policy toward Russia, i.a. via bilateral relations and the NATO and EU structures. However, it was not able to influence Russia's policy toward Germany in the same way, i.a. due to the dominance of disputable elements in the Polish-Russian relations, their critical nature and its own frequently confrontational policy toward Russia.

\section{Main dilemmas of the Polish foreign policy at the end of the second decade of the 21st century stemming from Poland's geopolitical location between Russia and Germany}

\section{In Poland's relations with Germany}

One of the main dilemmas present in Poland's relations with Germany concerned the constant increase of Germany's international role in the shaping of the EU and the international system in Europe and worldwide, including the growing superpower aspirations of that country's political decision makers. Bogdan Koszel used to emphasize that the period of German "circumspection" and "self-restraint" ended when Chancellor Helmut Kohl retired from politics in 1998. ${ }^{119}$ The subsequent governments of reunified Germany showed an increasing political will to accept greater responsibility for solving international problems. That process significantly intensified in the second decade of the 21st century, first of all due to the Euro area crisis, the conflict in eastern Ukraine and the refugee and migration crisis. The main role in the effort made to overcome the Euro area crisis and solve the refugee and migration crisis was played by Germany. ${ }^{120}$

Out of the two tendencies coexisting in Germany's foreign policy, self-restraint in the international arena and accepting the growing responsibility for solving international problems, the second decade of the 21 st century saw a definite strengthening of the second one. Germany's aspirations to increase its superpower role were confirmed in the most important document on the German security policy: the White Book. When German Minister of Defence Ursula von

119 B. Koszel: Mocarstwowe aspiracje Niemiec w Europie XXI wieku. Realia i perspektywy. Raport z badań. Poznań 2012, p. 16.

${ }^{120}$ See E CzIomer: Przestanki i wyzwania poszukiwania nowej roli międzynarodowej Niemiec $w$ dobie narastajacych kryzysów Unii Europejskiej - wybrane problemy badań i praktyki politycznej w XXI wieku. "Krakowskie Studia Międzynarodowe" 2016, nr 1, p. $21-49$. 
der Leyen presented the White Book in Berlin on 13 July 2016, she underlined that Germany was ready to take over the leading role in the solving of political and humanitarian crises worldwide depending on the country's capabilities. "We are ready to assume responsibility and become the leader, but we know our limitations", said U. von der Leyen at a press conference. ${ }^{121}$ The authors of the White Book saw Germany as a co-founder of a global international order. ${ }^{122}$

The problem for Poland and other countries was not the mere growth of Germany's international (superpower) role, ${ }^{123}$ but the ways and forms of that growth and the degree of acceptance for Germany's suggested solutions to the problems appearing inside and outside the EU. Polish politicians took various stances on Germany's growing international role. On the one hand, some of them encouraged Germany to assume increasing responsibility for solving international problems in Europe. An example was the address delivered by Polish Minister of Foreign Affairs Radosław Sikorski in Berlin (28 November 2011), in which he called Germany to assume leadership but not dominance. ${ }^{124}$ One the other hand, certain politicians, especially those from the PiS management, as well as a considerable part of the journalists and analysts supporting that political party, stated that it was another manifestation of the PO/PSL government's policy which aimed to turn Poland into Germany's voluntary satellite. ${ }^{125}$ The government led by Prime Minister B. Szydło diminished Germany's role in the Polish foreign policy, which was exemplified i.a. by Germany's distant position in the exposé delivered by Polish Minister of Foreign Affairs W. Waszczykowski in the Polish parliament at the end of January 2016. ${ }^{126}$ In practice, the PolishGerman relations in the years 2016-2017 cooled considerably. In an interview from March 2017, Chair of PiS Jarosław Kaczyński stated, "Germany conducts a policy directed against our interests on all the important matters, from histori-

${ }^{121}$ Berlin wydat Biała Księgę: zmienity się Niemcy oraz ich rola $w$ świecie - http:// www.tvn24.pl/wiadomosci-ze-swiata,2/berlin-wydal-biała-ksiege-zmieniły-sie-niemcy-orazich-rola-w-swiecie,660713.html (accessed: 20.01.2017).

122 See K. Szubart: Biała Ksiega 2016 - niemiecka odpowiedź na obecne wyzwania w zakresie bezpieczeństwa. "Biuletyn Instytutu Zachodniego", nr 266, 16 August 2016.

${ }^{123}$ See more in M. Stolarczyк: Wzrost mocarstwowej pozycji Niemiec...

124 R. Sikorski: Schytek Unii nie jest przesadzony. "Gazeta Wyborcza", 30 November 2011. In the same address, Minister R. Sikorski stated that he was probably the first Polish Minister of Foreign Affairs in history to say, "I fear German power less than I am beginning to fear German inactivity". R. SikoRSKI: Schytek Unii nie jest przesadzony...

125 See P. Żurawski vel Grajewski: Polska wobec przywództwa Niemiec w Unii Europejskiej. "Przegląd Zachodni" 2014, nr 1; M. MaGierowski: W roli przyzwoitki. "Uważam Rze", 5-11 December 2011; Ł. Warzecha: Satelita Niemiec. "Rzeczpospolita", 3 April 2012.

126 Information on the Polish Foreign Policy Tasks in 2016, Presented by Polish Minister of Foreign Affairs Witold Waszczykowski in the Polish Parliament on 29 January 2016 http://msz.govpl/aktualnosci/wiadomosci/minister_witold_waszczykowski_o_priorytetach_ polskiej_dyplomacji accessed: 3.02.2016). 
cal policy to energy supply." 127 The Polish-German relations slightly improved in 2018, when Mateusz Morawiecki was the Polish Prime Minister and Jacek Czaputowicz was the Minister of Foreign Affairs in his government. ${ }^{128}$

The growth of Germany's superpower role sometimes results in forecasts that Germany will become a global superpower because Europe will soon prove too small for that country ${ }^{129}$. The second decade of the 21st century saw the strengthening of the German tendency to change from an EU head into a dominant state or even a hegemonic leader. ${ }^{130}$ This raises questions about the implications of that situation for further European integration. Aleksander Smolar remarks that Germany's becoming the hegemonic leader exposes Europe's problem. ${ }^{131}$ According to Roman Kuźniar, a worrying aspect of Germany's politics is the fact that the country increasingly often takes the floor in the name (instead) of the EU and makes unilateral decisions which strain the entire Community. "Germany is rising above the European Union and begins to replace it in global contacts. This does not help the EU and does not have to be good for its interests." 132 The same author posed the following question: What are the longlasting consequences that might be suffered by European geopolitics due to the situation where the EU is weak, while Germany is strong and begins to rise above the EU or stand next to it? ${ }^{133}$

French political scientist Emmanuel Todd said in an interview, "Germany will be increasingly stronger and Poland will be doomed to it. One reason is that there is no counterbalance to Germany in contemporary Europe. Europe is no longer a counterbalance to Germany: it does as Germany says."134

Another extremely important issue is the degree to which the policy conducted by President of the United States Donald Trump, including his criticism of the EU integration process, support for Brexit and perception of the EU as a German domination tool, will influence Germany's role in the EU and in Eu-

127 Kaczyński: Na szczycie w Rzymie również trzeba zachować się zdecydowanie http://wiadomosci.wp.pl/kat,1342,title,kaczynski-na-szczycie-w-Rzymie-rowniez-trzeba-za chowac-s1e-zdecydowan1e,w1d,18731189,w1adomosc.html|(accessed: 20.03.2017).

${ }^{28}$ Minister Jacek Czaputowicz o priorytetach polskiej dyplomacji $w$ roku 2018...

129 R. Antczak: Niemcy - za duże na Europę, za małe na świat, ale da się to zmienić. "Wprost" 2016, nr 33.

130 See more in M. Stolarczyк: Kryzys uznanego (powszechnie akceptowanego) przywództwa Niemiec $w$ Unii Europejskiej. W: Kryzysy w Unii Europejskiej w drugiej dekadzie XXI wieku. Uwarunkowania — przebieg — implikacje. Red. T. Kubin, M. StolarczyK. Katowice 2018.

131 A. Smolar: Kłopoty wymusza integrację. Rozmowa z A. Smolarem. "Tygodnik Powszechny" 2016, nr 1-2.

132 R. Kuźniar: Przegląd sytuacji strategicznej — aspekty globalne i regionalne. "Rocznik Strategiczny" 2015/2016", T. 21, p. 28.

133 Ibidem, p. 29.

134 Brutalna Europa. Rozmowa z Emmanuelem Toddem. "Newsweek" 2015, nr 30, p. 45. 
rope. What stance should Poland take in the American-German dispute, including the striving to weaken Germany's position? Good relations with the USA are in Poland's interests provided that they supplement and not substitute Polish relations with the FRG, France and other countries. It is true that one of the biggest hazards to Poland's geopolitical situation which must be avoided is bad relations with Russia and Germany simultaneously. ${ }^{135}$

There are many signs that the growth of Germany's dominant role in the EU will strengthen in the oncoming years. At the same time, the crisis of Germany's acknowledged (commonly accepted) leadership in the EU is progressing. ${ }^{136}$ This process may be a significant factor accelerating the disintegration of the EU as we know it. It would mean a considerably accelerated implementation of the "German Europe" scenario and departing from the "European Germany" conception. ${ }^{137}$ This raises several questions: What will the implementation of that scenario imply for the European international system as well as the foreign and security policies of Poland and other states? Is it justified to fear that Germany's increasing tendency to dominate or even change into a hegemonic leader will result in the formation of Mitteleuropa as that country's zone of influence? ${ }^{138}$ Due to the crises emerging in the EU, the forecasts mentioning progressive EU disintegration or even its collapse and the evolution of the post-Cold War international system (from unipolarity to multipolarity), some people believed that those processes would result in the formation of three zones of influence in Europe: the French zone in Western and Southern Europe, Mitteleuropa led by Germany and the Russian zone in the area of former USSR. ${ }^{139}$

Taking into account Germany's role as Europe's biggest superpower not only in economy, but also in political terms, the extremely important challenges to the Polish foreign policy are contained in the following questions: Is it in Poland's interests to support most of Germany's actions in the EU and beyond? Does the Trimarium conception, which has been promoted since the end of 2015 and assumes the consolidation (formation) of a block of Central European states from the Baltic Sea to the Black Sea and the Adriatic Sea under Poland's leadership (12 states), relate only to the sense of a hazard posed by Russia regarding energy security (mainly gas supplies) or does it also concern, albeit to a lesser extent, the German hazard (an attempt to counterbalance Germany's

135 A. Talaga: Dmuchać na Niemcy. "Rzeczpospolita", 23 December 2015.

136 See more on this topic in M. Stolarczyк: Kryzys uznanego (powszechnie akceptowanego) przywództwa Niemiec...

137 See H. Kundnami: The Paradox of German Power. Oxford 2015.

138 Niemcy na drodze do Mitteleuropy. Dyskusja. "Polityka Polska" 2016, nr 7-8; compare: B. Koszel: Mitteleuropa rediviva? Europa Środkowo- $i$ Poludniowo-Wschodnia w polityce zjednoczonych Niemiec. Poznań 1999.

139 T. Marczak: Oś Paryż - Berlin - Moskwa a Międzymorze. "Polityka Polska" 2016, nr 7-8, p. 36. 
dominant role in the EU)? Is Trimarium, as an idea supported by the administration of Donald Trump, an instrument used by the USA to weaken the EU in its present form by intensifying its internal divisions and strengthening the USA's influence in the Trimarium Member States? Is that project being implemented mainly because of the aim to block the construction of Nord Stream II, inhibit Russian-German cooperation on Russian gas import to Germany and other states and increase the supplies of American liquefied gas to the Trimarium Member States? ${ }^{140}$ The decisive support of President D. Trump for Trimarium, including his participation in the second Trimarium summit in Warsaw (6-7 July 2017) and his encouragement to buy American gas, seems to make the above questions justified.

It also seems justified to ask: Does the promotion of Trimarium by Polish diplomacy match the American policy of treating Poland instrumentally as a wedge supposed to prevent closer cooperation between Germany and Russia? George Friedman, one of the most influential American political scientists, writes that one of the main objectives of the American foreign policy is the prevention of integration between the Russian resource base and workforce with the European technological progress, first and foremost the German progress. The USA's objective in Eurasia, defined as Russia and the European Peninsula, is to prevent one force (or coalition of forces) from dominating in that area. As G. Friedman argues, Russia integrated with Europe could form a superpower which might equal or even outclass America. Consequently, the USA should do everything in its power to prevent the German-Russian cooperation from becoming closer. The Intermarium states are indispensable for such American policy, and the biggest among them is Poland; in addition, its strategic location is the most advantageous one. The USA's relations with Poland can play two roles: prevent or weaken the German-Russian alliance or, if this fails, create a counterbalance for that alliance. The maintenance of a strong wedge in the form of Poland, driven in between Germany and Russia, is one of America's vital interests. ${ }^{141}$ In the American strategy, Poland is supposed to play — and has played for ages - one of the main roles in preventing the rapprochement between Russia and Germany as it could threaten America's hegemony in future decades. ${ }^{142}$

I reckon it was due to the abovementioned actual yet not declared reasons for Trimarium establishment that Germany declared its willingness to become a Trimarium partner at the end of July 2018 even though it had previously been sceptical about the entire idea. At the invitation of the Romanian hosts, Ger-

140 A. Bieńczyk-Missala: Od Międzymorza do Trójmorza - meandry polityki zagra nicznej Polski w Europie Środkowej. "Stosunki Międzynarodowe — International Relations" 2018, nr 1.

${ }^{141}$ G. Friedman: Następna dekada. Gdzie byliśmy i doką zmierzamy. Przeł. M. WyrwasWiŚNIEWSKA. Kraków 2012, p. 165-171.

${ }^{142}$ Ibidem, p. 205. 
man Minister of Foreign Affairs Heiko Maas participated in the third Trimarium summit held in Bucharest (17-18 September 2018). It was even suggested that Germany was interested in obtaining Trimarium membership. This raises the following question: Does Germany's participation in Trimarium really tally with the idea behind the establishment of that project and will it influence the effectiveness of accomplishing its objectives as expected by Polish diplomacy?

\section{In Poland's relations with Russia}

The Russian-Ukrainian conflict, which has lasted in eastern Ukraine since April 2014 and includes civil war elements, significantly worsened Poland's geopolitical situation. As a result, the sense of a hazard perceived by a significant part of Polish society considerably increased. ${ }^{143}$ When listening to numerous Polish politicians, journalists and analysts of international affairs, especially in 2014, one was able to conclude that the Russian army was preparing for an invasion of Poland. ${ }^{144}$ The National Security Strategy of the Republic of Poland signed by the President of Poland on 5 November 2014 included provisions which stated that, as a result of the crisis and then conflict in eastern Ukraine, including Crimea incorporation by Russia and the latter's support for the proRussian separatists in eastern Ukraine, Russia was the main military hazard to Poland's security ${ }^{145}$ At that time, the notion of a war with Russia was making headlines in Poland as numerous Polish politicians, journalists, service people and international affairs analysts seemed to be striving after a confrontation or even war with Russia. This does not mean, however, that Russia threatened Poland with a military invasion in the years 2014-2018. Russian authorities did not intend to commence any armed conflict with Poland. In one of his interviews, General Mieczysław Bieniek said, "An armed conflict between Russia and Poland is presently excluded. If someone mentions it, all I can say is they do not have their feet firmly fixed on the ground." 146 Stanisław Bielen writes that the thesis spread by Polish politicians and generals responsible for the security strategy, according to which "the enemy was at the door" and one had to get

${ }^{143}$ In a survey conducted by CBOS (Public Opinion Research Centre) on 3-9 April 2014, 47\% of respondents reckoned that Poland's independence was threatened in the context of the events in Ukraine. $29 \%$ of respondents believed that Poland was threatened with a Russian military attack. Polacy o bezpieczeństwie narodowym i NATO Komunikat z badań CBOS. Oprac. K. KowALCZYK. Warszawa 2014, nr 48 - www.cbos.pl/SPISKOM. POL/2014K_048PDF (accessed: 10.08.2014).

See more in M. StolarczyK: Rosja w polityce zagranicznej Polski...

145 The National Security Strategy of the Republic of Poland. Warsaw 2014, p. $20-$ www.mon.gov.pl (accessed: 10.12.2014).

Pierwszy atak będzie w cyberprzestrzeni. Rozmowa z gen. Mieczysławem Bieńkiem. "Przegląd", 20-26 October 2014. 
ready for a war, did not stem from an analysis of the real strategic situation, but from an anti-Russian obsession and the disastrous consequences of the involvement in Ukraine's internal affairs. ${ }^{147}$ The atmosphere of fear of a Russian invasion, created by Polish ruling groups and the media that supported them, favoured the militarisation of Polish politics and a significant increase of the expenditure on armaments (2.5\% of GDP till 2024).

In 2014 and subsequent years, the relations between Poland and Russia on the highest level were frozen. In the years 2014-2019, subsequent Polish governments were in favour of maintaining the economic sanctions imposed on Russia and the political isolation of Russian authorities. Russia ended its political isolation relatively fast and in recent years its President V. Putin met Presidents of the USA (Barack Obama and Donald Trump) and France (Emmanuel Macron), FRG Chancellor Angela Merkel as well as many other presidents and Prime Ministers of other NATO and EU Member States. Polish diplomacy occasionally declared the will to improve the relations with Russia, e.g. during the exposés delivered by subsequent Polish Ministers of Foreign Affairs, ${ }^{148}$ but it did not demonstrate any significant practical interest in that improvement. In his exposé delivered in the Polish parliament on 9 February 2017, Polish Minister of Foreign Affairs Witold Waszczykowski underlined that Polish policy toward the Russian Federation was conditioned by Russia's aggressive actions in Eastern Europe. Still, he claimed that the government saw the need for conducting a dialogue with Russia as it was Poland's neighbour. ${ }^{149}$ The next Polish Minister of Foreign Affairs Jacek Czaputowicz delivered his exposé in the Polish parliament on 21 March 2018. On the one hand, he stressed that Russia's policy was a hazard to the building of Poland's autonomous position in international relations. On the other hand, he stated that pragmatic relations with the Russian Federation were in Poland's and Europe's interests. He said that the government viewed the maintenance of a political dialogue with Russia as indispensable. However, he

147 Żeby Polska nie przegapiła szansy na dialog z Rosja - n 1 d,1548975,nPack,3 - http:/ fakty.interia.pl/tylko-u-nas/news-prof-stanislaw-bielen-zeby-polska-n1e-przegapila-szansyna-d, (accessed: 10.11.2014).

The exposé delivered in the Polish parliament on 29 January 2016 by Polish Minister of Foreign Affairs Witold Waszczykowski featured i.a. a statement that pragmatic and matterof-fact relations with the Russian Federation were in Poland's and Europe's interests. He declared his will to cooperate with Russia, in particular on such issues as: reliable collaboration on investigating the Smolensk disaster causes; returning the wreck of the Polish President's plane; and full declassification of the archives recording the Stalinist regime crimes the victims of which were Polish officers. Information on the Polish foreign policy tasks in 2016, presented by Polish Minister of Foreign Affairs Witold Waszczykowski in the Polish parliament on 29 January 2016 - msz.gov.pl (accessed: 3.02.2016).

${ }_{149}$ Minister Witold Waszczykowski o priorytetach polskiej dyplomacji w 2017 roku h thtp://www.msz.gov.pl/pl/p/msz_pl/aktualnosci/minister_witold_waszczykowski_o_priory tetach_polskiej_dyplomacji_w_2017_roku (accessed: 10.02.2017). 
simultaneously asserted, "Ignoring Russia's present aggressive policy toward the West must not constitute the essence of that dialogue." ${ }^{150}$ Despite those declarations, neither Poland nor Russia showed any political will to improve the mutual relations. Representatives of Russian authorities highlighted that the crisis in the Polish-Russian relations should be resolved by Poland because it was not Russia that discontinued the contacts. ${ }^{151}$

The attitude toward Russia demonstrated by Polish authorities in the years 2014-2019 was one of the most uncompromising among the EU and NATO Member States. At the same time, politicians from other countries, first and foremost Germany, conducted a constant albeit difficult dialogue with Russia. The relevant discussion both in Poland and Russia was dominated by unfavourable comments on the other party and blaming each other for the crisis of the Polish-Russian political relations. Poland stressed first and foremost Russia's breach of the fundamental provisions of international law via Crimea incorporation and supporting the pro-Russian separatists in eastern Ukraine as well as demanded returning the remnants of the Polish President's plane which had crashed near Smolensk on 10 April 2010. In turn, a matter very important to Russia in its dispute with Poland was the disassembly of Polish monuments to Soviet soldiers and officers, approx. 600 thousands of which had died in the territory of contemporary Poland in the fights with the German army. Russia accused Polish authorities of escalating "a war with the monuments" commemorating the Soviet soldiers who had laid down their lives to save the Polish state and nation from Nazism, lack of a historical memory and breaching the PolishRussian agreement of 22 February 1994 on graves and memorial sites of victims of wars and repressions. Poland argued that the Polish-Russian memorial agreement was observed because the Polish state took care of cemeteries and burial sites, while decisions on monuments were made by local authorities. An argument widely acknowledged in Poland was that the monuments commemorating the Red Army soldiers who had died in the territory of Poland were not homage to those who had fallen but a symbol of dependence on the Soviet Empire.

In the context of the conflict in eastern Ukraine, both scientific studies and political journalism texts published in Poland in recent years contained opinions that it was necessary to determine new rules of the policy toward Russia. However, the exact nature of those new rules was perceived in a greatly diversified manner. For some (a vast majority), it meant a significant toughening of Polish policy toward Russia. For others (a definite minority), it meant deriving essential conclusions from the previous failures of the Polish Eastern policy and

${ }^{150}$ Minister Jacek Czaputowicz o priorytetach polskiej dyplomacji w 2018 roku http://www.msz.gov.pl/pl/aktualnosci/minister_jacek_czaputowicz_o_priorytetach_pols k1ej_dyplomacj1_w_2018_roku (accessed: 25.04.2018).

Zielonych ludzików w Polsce nie będzie. Wywiad z ambasadorem Rosji w Polsce, Siergiejem Andriejewem. "Rzeczpospolita", 26 November 2015. 
a considerable reorganisation of its hierarchy of values to make it more realistic in comparison with the one pursued till the end of 2015. It is true that the PiS governments slightly modified Poland's previous Eastern policy, mainly in the historical area and first of all toward Ukraine. They also distanced themselves from Eastern Partnership - a flagship project pursued by the PO party in the Eastern policy.

Concerning the conflict in eastern Ukraine, one of the most important dilemmas in the Polish Eastern policy, including the policy toward Russia, is included in the search for an answer to the following question: Should the Polish Eastern policy to date be assessed as a success or failure? Depending on the answer, that policy should be continued, modified (to what extent?) or thoroughly changed. Despite the stance that the Polish Eastern policy after 1989 should be assessed positively, which prevails in the Polish political elite and the Polish media, this matter raises a number of doubts concerning i.a. excessive involvement of Polish politicians in Ukraine's internal affairs, their uncritical support for the post-Maidan authorities, lack of Polish (governmental) proposals regarding the manners of de-escalating the Ukrainian conflict using diplomatic instead of military means and the critical stance of Polish authorities on the Minsk I and Minsk II agreements.

An extremely important aspect of this assessment seems the fact that the conflict in eastern Ukraine falsified Poland's role as the EU's main expert on the matters of the post-Soviet region. Throughout many years, Poland had aspired to the role of Ukraine's chief defender in the EU, but it lost that position to Germany during the Ukrainian conflict. The FRG government assumed the main responsibility for ending that conflict and stabilising the situation in Eastern Europe in the name of Germany and the EU. In subsequent years after 2013, Ukrainian politicians were gradually becoming less interested in having Poland as Ukraine's defender in the EU. They simultaneously made effort to have Germany play that role. One should mention here that the Polish-Ukrainian relations deteriorated significantly after 2015, especially due to the different assessments by Poland and Ukraine of the Volhynia genocide committed by Ukrainian Insurgent Army (UPA) troops during World War II and the progressive glorification of UPA's actions by Ukrainian authorities (the official heroisation of the Bandera movement). ${ }^{152}$ One direct consequence of the change of authorities in Kiev in 2014 was the strengthening of nationalist ideas in Ukrainian society, first of all in western Ukraine. In the years 2017-2018, the Polish-Ukrainian relations reached their worst condition since 1991. PiS politicians used to say that Ukraine would not join the EU with Bandera. Consequently, Polish political journalists

${ }^{152}$ Volodymyr Viatrovych, Director of the Ukrainian Institute of National Remembrance, argued that the crimes during World War II had been symmetrical on the Ukrainian and Polish sides. Zbrodnie byty symetryczne. "Rzeczpospolita", 14 July 2016. 
began to remark that Poland's role in the Ukrainian foreign policy underwent a great revolution - from a defender to a prosecutor.

The implementation of Eastern Partnership proved rather ineffective as well. ${ }^{153}$ It was justified to state that the Polish government's tactics, which combined the normalisation of the relations with Russia with a simultaneous effort to enhance the EU's influence in the post-Soviet region via Eastern Partnership, ended in failure. ${ }^{154}$ Consequently, Eastern Partnership, which was one of the most important initiatives undertaken by Polish diplomacy in the post-Cold War period and in which Ukraine was supposed to play the leading role, did not produce the desired results. Jędrzej Bielecki writes, "Poland's idea of a conflict-free integration of Ukraine with the EU fell flat." 155 The idea of integrating Ukraine with the EU while simultaneously "pushing" Russia away toward Asia did not have the anticipated effect. The same author accurately remarks that the Polish Eastern policy has to face a new serious dilemma expressed in the following question: Should Poland join the German and French effort to normalise the relations with Russia at the cost of giving up on Ukraine's dreams of integration with the EU or should it stick to the present vision, which is courageous but not too realistic ${ }^{156}$ ? Other strategic dilemmas of Polish policy toward Russia, which I have already described in greater detail in another work, are contained in the search for the answers to the following questions: Is Russia an enemy, a rival or just a difficult partner in the Polish security policy? With regard to Polish interests, should Polish diplomacy become involved in Russia's Europeanisation or international isolation? Should Poland choose Russia or Ukraine as the main partner in the post-Soviet region ${ }^{157}$ ?

Another very important dilemma in the Polish Eastern policy and beyond is contained in the following question: Can the Polish Eastern policy be effective without relevant cooperation with Germany? Robert Foks justifiably argues that, if Poland wishes to cooperate more closely with Germany on the shaping of the EU's Eastern policy, the decision makers of the Polish foreign policy will have to resume the process of normalising Poland's relations with Russia and reorganise the hierarchy of values in the Polish policy toward Ukraine conducted to date. ${ }^{158}$ An alternative solution to a significantly changed Polish Eastern policy, founded on the Polish-German cooperation to build partner-

${ }_{153}$ R. FoKs: Kluczowe wyzwania i uwarunkowania dla polskiej polityki wschodniej po zmianie władzy w Polsce w 2015 r. "Dyplomacja i Bezpieczeństwo" 2016, nr 1, p. 136.

154 R. FoKs: Polska i Niemcy a polityka wschodnia Unii Europejskiej. "Dyplomacja i Bezpieczeństwo" 2014, nr 1, p. 123.

155 J. BIELECKI: Potrzebne jest nowe otwarcie. "Rzeczpospolita", 2 January 2015.

156 Ibidem.

157 See more in M. Stolarczyк: Rosja w polityce zagranicznej Polski..., p. 401 and subs. pages.

158 R. FoKs: Polska i Niemcy a polityka wschodnia Unii Europejskiej..., p. 132-133. 
ship-based and non-confrontational relations with Russia, was a proposal to develop the Polish-German cooperation on the Eastern policy via closer collaboration of both countries with Ukraine and "weakening the potential for aggression" demonstrated by Russia. ${ }^{159}$ The advocates of that stance argued that Germany should be the leader in the fight against Putin and the strategy of stopping Russian imperialism, while Poland ought to play an important role in that strategy as the most powerful country in the region. ${ }^{160}$ However, the hope that Germany would conduct a confrontational policy toward Russia significantly differed from the relevant tendencies appearing in German Ostpolitik in recent years. The White Book, a new conception of national security adopted in July 2016, contained i.a. a statement that, unless the direction of actions was completely changed, Russia would constitute a challenge to the security in Europe in the oncoming years. At the same time, Europe and Russia are connected via a broad range of mutual interests and relations. As the EU's biggest neighbour and a permanent member of the UN Security Council, Russia bears special responsibility, both regionally and globally, for tackling international challenges and crises. "In the future, one will not achieve sustainable security or progress in and for Europe without Russia, either. In this sense, it is important to treat Russia as a specific mix of collective responsibility and building a protection, while creating the premises for cooperative security and industry collaboration." "161 Still, Russia's actions, especially those concerning Ukraine, do require a double approach based on mutual deterrence and defensive capacity as well as readiness for dialogue. ${ }^{162}$ Even though the FRG modified its policy toward Germany after 2013, its main assumptions from the previous period were sustained. They include: Germany's effort to treat Russia as a partner, not an enemy; maintaining the focus on cooperation instead of confrontation with Russia; perception of Russia by FRG authorities as "the main player" in the post-Soviet region; treating Russia as the main subject in the security policy and economy of the CIS area; highlighting by the FRG ruling groups of the will to act as a mediator and agent between Russia and the West. ${ }^{163}$ The increase of controversy in the German-American relations during the term of office served by President D. Trump may be an important determinant making the German-Russian cooperation closer.

159 M.A. Сıсноскі, O. Osica: Nowa polsko-niemiecka agenda. Jak przekuć różnice w podstawę wspólnych interesów? "Dialog" 2015, nr 1, p. 57.

${ }^{160}$ M. Czech: Nasze miejsce w grze o Ukrainę. "Gazeta Wyborcza”, 6 March 2015.

${ }_{161}$ Das Weissbuch zur Sicherheitspolitik und der Zukunft der Bundeshwer, Berlin 2016, p. 32 - h/tps://www.bmvg.de/portal/a/bmvg/!ut/p/c4/04_SB8K8xLLM9MSSzPy8xBz9CP315EyrpHK9pNyydL3yIMz14q1S5A (accessed: 12.11.2016).

102 Ibidem.

${ }^{163}$ See more in M. Stolarczyк: Bezpieczeństwo Niemiec $w$ kontekście konfliktu na wschodzie Ukrainy. "Bezpieczeństwo. Teoria i Praktyka" 2017, nr. 1, p. 83-97. 
Given the abovementioned differences between the Eastern policies of Poland and Germany, it seems justified to infer that there is little possibility of making the cooperation of the two countries closer in the scope of their policies toward Russia and Ukraine in the oncoming years. There are no suitable grounds for claiming that the Eastern policies of Poland or Germany, including their policies toward Russia and Ukraine, will undergo fundamental changes. Only such thorough changes in the policy of either country would enable a considerable rapprochement of stances and enable both governments to cooperate on a wide scale in this scope. It is rather unrealistic to assume that the present Polish Eastern policy may soon undergo a thorough reorganisation of its hierarchy of values. On the contrary, the Ukrainian crisis and conflict strengthened the current assumptions of Poland's policy toward Russia, at least in the short term. Neither the Polish political elites and opinion-forming circles nor the majority of Polish society created a suitable political atmosphere or showed their will to make the cooperation with Russia closer instead of striving after a confrontation. ${ }^{164}$ An example of extreme thinking in this aspect is the writing by Andrzej Talaga published in the "Rzeczpospolita" daily paper, where he justifies a thesis that the worse the Polish-Russian relations the better for Poland's security. ${ }^{165}$ Moreover, the decision makers of the Polish foreign policy showed no political will to cooperate more closely with Germany on the shaping of the EU's Eastern policy based on the normalisation of the relations with Russia, including the acceptance of Germany's two-way policy toward Russia (deterrence and dialogue). ${ }^{166}$ The decision makers of the Polish foreign policy had no idea

164 In 2018, the opinions that an improvement of the relations with Russia was justified, expressed by politicians and journalists such as Kornel Morawiecki or Rafał Ziemkiewicz, were isolated voices.

165 According to Andrzej Talaga, if Poland's relations with Russia are normalised, it will become difficult to keep Polish society convinced that the expenditure on armaments should be regularly increased. The reason for the stationing of a NATO battalion and an American brigade in the territory of Poland will cease to be valid. The premises for intensifying the coordination of the alliance's armies via training ground exercises will no longer exist. There will also be no reason for Western European states to increase their defence budgets to the level of 2\% of GDP. A. TALAGA: Reset z Rosja to duże zagrożenie. "Rzeczpospolita", 30-31 May 2018. In A. Talaga's opinion, Russia, whether authoritarian or liberal, will never be on friendly terms with Poland because geopolitics dooms the two countries to coexist in a conflict. A. Talaga: Wieczny konflikt z Rosja. "Rzeczpospolita", 9 May 2018; A. Talaga: Lepiej z Banderq niż z Moskwa. "Rzeczpospolita", 23 August 2017.

166 See R. FoKs: Kluczowe wyzwania $i$ uwarunkowania dla polskiej polityki wschodniej.... Katarzyna Pełczyńska-Nałęcz, a former ambassador of Poland in Russia, mentions seven myths paralysing Polish policy toward Russia in her text written near the end of 2016. They include i.a. the following ones: Russia is bad (aggressive, hypocritical, non-democratic), so one should not conduct talks with it; every dialogue with Russia is doomed to failure; conducting a dialogue with Russia equals a betrayal of Polish interests; freezing the WarsawMoscow contacts makes it difficult for the West to pursue its policy of improving the relations 
for arranging the relations with Russia. A considerable weakening of Poland's position in the EU in recent years as well as the large number of disputable issues present in the Polish-Russian relations, including the confrontational policy of Polish authorities toward Russia, prevented the Russian ruling groups from becoming interested in the normalisation of their relations with Poland.

It is also rather unlikely that the cooperation between Poland and Germany on the shaping of their policy toward Russia will become closer due to a fundamental change of Germany's present Eastern policy making it similar to the main assumptions of Poland's Eastern policy. Thus far, the policy implemented by German authorities offers no grounds for inferring that Germany is striving for a thorough change of its present policy toward Russia from cooperative to confrontational. ${ }^{167}$ One should answer the following question: What would be the consequences (also for Poland) of a fundamental change of Germany's present policy toward the post-Soviet region? It is highly probable that the essence of such change would be closer German-Ukrainian cooperation and treatment of Ukraine as a strategic partner in Germany's Eastern policy. Given the increasing nationalist tendencies in Ukraine, including anti-Polish trends, would closer German-Ukrainian cooperation be favourable to Poland?

\section{Conclusion}

Despite the very important changes taking place in the post-Cold War period in Poland's immediate and further international environment, including the influence of globalisation and increasing interdependencies, the geopolitical factor still plays a truly significant role in the shaping of Polish foreign policy. Its essence comes down to Poland's geopolitical location between Germany (reunified since 1990) and the Russian Federation, the strongest organism in the area of former USSR. However, Tomasz Orłowski justifiably argues that the geopolitical factor, whether for Poland or other countries, is not an independent prime mover; it does not entail geopolitical determinism which automatically eliminates the possibility of influencing Poland's situation by its authorities. ${ }^{168}$

with Russia; Poland's uncompromising policy toward Russia defends the interests of Ukraine and Belarus. Dyplomacja romantyczna. Oto siedem mitów, które paraliżuja polska polityke wobec Rosji - http://www.polityka.pl/tygodnikpolityka/swiat/1681052,2,stosunki-polskarosja-obalamy-7-mitow.read (accessed: 26.03.2017).

See more in M. Stolarczyк: Możliwości wspótdziałania Polski i Niemiec w zakresie ich polityki wobec Rosji i Ukrainy. "Krakowskie Studia Międzynarodowe" 2016, nr 2, p. $123-149$.

168 T. Orıowski: Geopolityka polska. W: C. JeAn: Geopolityka..., p. 362. 
Poland's geopolitical location between Russia and Germany does not doom Polish relations with the two countries to a confrontational nature for historical reasons. In the post-Cold War period, that concerned first and foremost the Polish-Russian relations and a thesis highlighted in Poland according to which the hazard posed by Russia to Poland was timeless. The geopolitical factor in its traditional sense shaped Poland's policy toward Russia to a much larger extent than it did the policy toward Germany. The significance of the German problem diminished considerably in the Polish foreign policy in the post-Cold War period, while the significance of the Russian problem remained considerable. As demonstrated by the Polish-German relations in the last 30 years, the geopolitical location does not determine eternal hostility between countries, the strength of Poland's autonomous position in the international arena or the effectiveness of the Polish foreign policy in Poland's relations with its two biggest neighbours. The geopolitical location does not determine eternal enemies or eternal friends because one can derive various conceptions, programmes and objectives of the foreign policy from the same geopolitical location of Poland. The key role in that period, beside the German and Russian policies toward Poland, was played by subsequent decision makers of the Polish foreign and security policies and their perception of international reality, including the perception of challenges and hazards to Poland's interests posed by its two biggest neighbours. In the new international reality, where Poland is an EU and NATO Member State, it should make effort to maintain good relations not only with Germany, but also with Russia. For those reasons, Adam Daniel Rotfeld reckons that "the eternal Polish dilemma whether security should be shaped together with Russia against Germany, together with Germany against Russia or via balancing between Russia and Germany like in the interwar period has ceased to exist." ${ }^{169}$ Still, the research on the Polish foreign policy shows that the stance according to which Poland's security should be built together with Germany against Russia was widely acknowledged in Polish society in the discussed period.

Given the degree of convergence and divergence of Polish interests with the German and Russian ones, there is little probability that Poland's relations with Russia and Germany will become better than the German-Russian relations. It is slightly more likely that Poland's relations with Russia and Germany in the long term will reach a similar level to that of the German-Russian relations. This also provokes the following question: How long will it take the Polish and Russian ruling groups to free the current Polish-Russian relations "from their enslavement to history and break the determinism of hostility" the way it has largely been accomplished in the Polish-German relations? I reckon that, despite the numerous areas of divergent interests in the Polish-Russian relations, the long-term Polish interests pursued in the post-Soviet region require broadening the scope

169 A.D. Rotfeld: W poszukiwaniu strategii..., p. 287. 
of cooperation with Russia as well as departing from the confrontational policy and perceiving Russia as an eternal, timeless enemy. The excessive emotionality typical of the Polish Eastern policy should be replaced with a policy of rationalism, including striving for Russia's gradual Europeanisation and Poland's simultaneous actions aimed at the Westernisation of Ukraine and Belarus (Westernisation of Eastern Europe together with Russia, not against Russia). One should realise that only this way will it become possible to reduce the tension caused by the geopolitical competition for the influence on Ukraine.

\section{Bibliography}

“Rocznik Strategiczny 2013/2014", T. 19.

"Rocznik Strategiczny 2018/2019”, T. 24.

Antczak R.: Niemcy - za duże na Europę, za małe na świat, ale da się to zmienić.

"Wprost" 2016, nr 33.

BAlcer A., WóyCicki K.: Polska na globalnej szachownicy. Warszawa 2014.

BALCER A.: Trójmorze - myślenie życzeniowe czy Realpolitik? "Dialog” 2017, nr 1.

Berlin wydat Biała Ksiege: zmienity sie Niemcy oraz ich rola $w$ świecie - http:// www.tvn24.pl/wiadomosci-ze-swiata, 2/berlin-wydal-biała-ksiege-zmieniły-sieniemcy-oraz-ich-rola-w-swiecie,660713.html (accessed: 20.01.2017).

BieleCKi J.: Potrzebne jest nowe otwarcie. "Rzeczpospolita", 2 January 2015.

BIELEŃ S.: Czas próby w stosunkach międzynarodowych. Warszawa 2017.

Bieleń S.: Polska między Niemcami a Rosja - determinizm czy pluralizm geopolityczny? W: Polityka zagraniczna Polski po wstapieniu do NATO i do Unii Europejskiej. Problemy tożsamości $i$ adaptacji. Red. S. BIELEŃ. Warszawa 2010.

Bieleń S.: Pozycja geopolityczna Polski. W: Polska w stosunkach międzynarodowych. Red. S. Bieleń. Warszawa 2007.

Bieleń S.: Stosunki Unia Europejska-Rosja. W: Dyplomacja czy siła? Unia Europejska $w$ stosunkach międzynarodowych. Red. S. PARzYMIES. Warszawa 2009.

BIELEŃ S.: Szanse na pojednanie polsko-rosyjskie w świetle wyzwań geopolitycznych. W: Geopolityka w stosunkach polsko-rosyjskich. Red. S. Bieleń, A. SKrzyPeK. Warszawa 2012.

BieńCZyk-Missala A.: Od Międzymorza do Trójmorza - meandry polityki zagranicznej Polski w Europie Środkowej. "Stosunki Międzynarodowe — International Relations" 2018, nr 1.

Bocheński A.: Między Niemcami a Rosja. Warszawa 1937.

Brutalna Europa. Rozmowa z Emmanuelem Toddem. "Newsweek" 2015, nr 30.

BrZeZiński Z.: Fiński model dla Ukrainy. "Gazeta Wyborcza”, 25 February 2014.

Buhler P.: O potędze w XXI wieku. Przeł. G. Majcher. Warszawa 2014. 
Buras P.: Polska-Niemcy: Partnerstwo dla Europy? Interesy, opinie elit, perspektywy. Warszawa 2013.

Cichocki M.A., Osica O.: Nowa polsko-niemiecka agenda. Jak przekuć różnice w podstawę wspólnych interesów? "Dialog" 2015, nr 1.

Cichоскі M.A.: Niemiecka polityka wobec Polski na nowych drogach? "Dialog" $2005 / 2006$.

Czarnocki A.: Koncepcje polityki zagranicznej Polski. W: Międzynarodowe stosunki polityczne. Red. M. PIETRaś. Lublin 2006.

Czech M.: Nasze miejsce w grze o Ukraine. "Gazeta Wyborcza”, 6 March 2015.

Cziomer E.: Przesłanki i wyzwania poszukiwania nowej roli międzynarodowej Niemiec $w$ dobie narastajacych kryzysów Unii Europejskiej - wybrane problemy badań i praktyki politycznej w XXI wieku. "Krakowskie Studia Międzynarodowe" 2016, nr 1.

Das Weissbuch zur Sicherheitspolitik und der Zukunft der Bundeshwer. Berlin 2016 - https://www.bmvg.de/portal/a/bmvg/!ut/p/c4/04 SB8K8xLLM9MSSzPy8xBz 9C-P315EyrpHK9pNyydL3y1Mzi4qTS5A (accessed: 12.11.2016).

Das Weissbuch zur Sicherheitspolitik und zur Zukunft der Bundeshwer, Berlin 2016 https://www.bmvg.de/portal/a/bmvg/!ut/p/c4/04 SB8K8xLLM9MSSzPy8xBz9 CyrpHK9pNyydL3y1Mzi4QTS5A (accessed: 12.11.2016).

DMOWski R.: Niemcy, Rosja i kwestia polska. Warszawa 1908.

DMowski R.: Niemcy, Rosja i kwestia polska. Wrocław 2000.

Dobroczyński M.: Między mocarstwami. Warszawa-Toruń 1996.

Dyplomacja romantyczna. Oto siedem mitów, które paraliżuja polska polityke wobec Rosji - http://www.polityka.pl/tygodnikpolityka/swiat/1681052,2,stosunki-pol ska-rosja-obalamy-7-mitow.read (accessed: 26.03.2017).

EBerhard P.: Polska i jej granice. Lublin 2004.

Ein neuer Aufbruch für Europa. Eine neue Dynamik für Deutschland. Ein neuer Zusammenhalt für CDU, CSU und SPD. Koalitonsvertrag zwischen CDU,CSU und SPD - dynamic.faz.net/download/2018.koalitionsvertrag.pdf (accessed: 9.08.2018).

Ekspert: polityka Polski wobec Niemiec oscyluje miedzy nieufnościa a wspótpraca http://wiadomosci.wp.pl/kat,1356,title,Ekspert-polityka-Polski-wobec-Niemiecoscyluje-miedzy-nieufnosia-a-wspołpraca,wid,18379882,wiadomosc.html?ti caid=11323 (accessed: 15.06.2016).

Erwachsene Nachbarschaft. Die feutsch-polnischen Beziehungen 1991 bis 2011. Hrsg. D. Bingen, P.O. Loew, K. Ruchniewicz, M. Zybura. Wiesbaden 2011.

Europa niebezpieczna sama dla siebie. Wywiad z George'em Friedmanem. "Rzeczpospolita", 1-2 September 2018.

Europa und die neue Deutsche Frage. Ein Gespräch mit Jürgen Habermas, Joschka Fischer, Henrich Enderlein und Christian Calliess. "Bläter für deutsche und internationale Politik" 2011, Nr 5.

Fedorowicz K.: Polityka Polski wobec Rosji, Ukrainy i Białorusi w latach 19892010. Poznań 2011.

Flint C.: Wstęp do geopolityki. Przeł. J. Halbersztat. Warszawa 2008.

FoKs R.: Kluczowe wyzwania i uwarunkowania dla polskiej polityki wschodniej po zmianie władzy w Polsce w 2015 r. "Dyplomacja i Bezpieczeństwo" 2016, nr 1. 
FoKs R.: Polska i Niemcy a polityka wschodnia Unii Europejskiej. "Dyplomacja i Bezpieczeństwo" 2014, nr 1.

Friedman G.: Następna dekada. Gdzie byliśmy $i$ dokad zmierzamy. Przeł. M. WyrWAS-WIŚNIEWSKA. Kraków 2012.

Generał Stanisław Koziej nie wyklucza inwazji Rosji na Polske - http://wiadomosci. wp.pl/kat,1342,title,General-Stanislaw-Koziej-nie-wyklucza-inwazji-Rosji-naPolske,wid,17272158,wiadomosc.html (accessed: 6.03.2015).

Geoekonomia. Red. E. HaLiżaK. Warszawa 2012.

Grudziński P.: Państwo inteligentne. Polska w poszukiwaniu międzynarodowej roli. Toruń 2008.

Hofman I.: Polska - Niemcy - Europa. Program zachodni paryskiej "Kultury". Lublin 2009.

https://www.bankier.pl/wiadomosc/Niemiecki-eksport-srubuje-rekordy-7571395. html (accessed: 29.08.2018).

https://www.dw.com/pl/szef-msz-niemiec-czas-na-nowa-wizje-partnerstwa-europyz-usa/a- (accessed: 12.10.2018).

https://www.rp.pl/Gospodarka/303189919-Wymiana-handlowa-Rosja-to-niestabilnyrynek (accessed: 1.10.2018).

Information on the Polish Foreign Policy Tasks in 2016, Presented by Polish Minister of Foreign Affairs Witold Waszczykowski in the Polish Parliament on 29 January 2016 - http://msz.govpl/aktualnosci/wiadomosci/minister witold waszczykowski_o_priorytetach_polskiej_dyplomacji (accessed: 3.02.2016).

Information on the Polish Foreign Policy Tasks in 2016, Presented by Polish Minister of Foreign Affairs Witold Waszczykowski in the Polish Parliament on 29 January 2016 - msz.gov.pl (accessed: 3.02.2016).

Information on the Polish Foreign Policy Tasks in 2016, Presented by Polish Minister of Foreign Affairs Witold Waszczykowski in the Polish Parliament on 29 January 2016 - http://msz.gov.pl/aktualnosci/wiadomosci/minister witold waszczykowski_o_priorytetach_polskiej_dyplomacji (accessed: 3.02.2016).

Interview with Henry Kissinger. Do We Achieve World Order Through Chaos or Insight? - www.spiegel.de/international/world/interview-with-henry-kissingeron-state-of-global-politics-a-1002073.html (accessed: 18.11.2014).

JANOWSKI K.B.: Polityka wschodnia RP - http://karol-b-jaowski.waw.pl/POLITY KA\%20WSCHODNIA\%RP.pdf (accessed: 4.09.2018).

JEAn C.: Geopolityka. Przeł. T. ORŁowsKi. Wrocław 2003.

Juchnowski R.: Miejsce geopolityki w polskiej myśli politycznej XIX i XX wieku. Toruń 2018.

Kaczyński: Na szczycie w Rzymie również trzeba zachować sie zdecydowanie http://wiadomosci.wp.pl/kat,1342,title,kaczynski-na-szczycie-w-Rzymierowniez-trzeba-zachowac-sie-zdecydowanie,wid,18731189,wiadomość.html (accessed: 20.03.2017).

KaRnOwsKi M.: Nowy bilans ofiar II wojny światowej opublikowany przez Instytut Pamięci Narodowej. "Dziennik", 26 August 2009.

Kolanko M.: Rosja już nie taka straszna. "Rzeczpospolita", 17 August 2017.

Koszel B.: Mitteleuropa rediviva? Europa Środkowo- i Poludniowo-Wschodnia w polityce zjednoczonych Niemiec. Poznań 1999. 
Koszel B.: Mocarstwowe aspiracje Niemiec w Europie XXI wieku: realia $i$ perspektywy. Raport z badań. Poznań 2012.

KunuŁka J.: Traktaty sqsiedzkie Polski odrodzonej. Wrocław 1998.

Kundnami H.: The Paradox of German Power. Oxford 2015.

Kuźniar R.: Droga do wolności. Polityka zagraniczna III Rzeczypospolitej. Warszawa 2008.

KUŹNIAR R.: Przeglad sytuacji strategicznej - aspekty globalne i regionalne. "Rocznik Strategiczny" 2015/2016”, T. 21.

LANG K.O.: Kłóćmy się, ale rozsądnie. "Rzeczpospolita", 26 January 2016.

Łagowski B.: Polska chora na Rosję. Warszawa 2016.

ŁaSTAWSKi K.: Dylematy współczesnej polskiej racji stanu. W: Polityka zagraniczna Polski $w$ zmieniajacym się ładzie międzynarodowym. Wybrane problemy. Red. R. Zį̨BA, T. PAwŁuszKo. Toruń 2016.

Łastawski K.: Pozycja geopolityczna Polski w Europie po rozpadzie bloku radzieckiego. W: Bezpieczeństwo międzynarodowe. Polska - Europa - Świat. Księga Jubileuszowa dedykowana Profesorowi Ryszardowi Ziębie z okazji czterdziestolecia pracy naukowej. Red. J. Zając, A. WŁodKowska-Bagan, M. KaCzMaRSKI. Warszawa 2015.

Magierowski M.: W roli przyzwoitki. "Uważam Rze”, 5-11 December 2011.

Malinowski K.: Polska i Niemcy w Europie (2004-2014). Różnice interesów uwarunkowania i konsekwencje. Poznań 2015.

Marczak T.: Oś Paryż - Berlin - Moskwa a Międzymorze. "Polityka Polska" 2016, nr 7-8.

MARSZAŁeK A.: Europejska idea integracji międzynarodowej w perspektywie historycznej. Toruń 2008.

MarszaleK A.: Polskie dyskusje o integracji europejskiej po II wojnie światowej $w$ historycznej perspektywie porównawczej. Wybrane zagadnienia. Toruń 2010.

Mazur Z.: Centrum przeciwko Wypędzeniom (1999-2005). Poznań 2006.

Minister Jacek Czaputowicz o priorytetach polskiej dyplomacji w 2018 roku - http:// WwW.msz.gov/pl/pl/aktualnosci/wiadomosci/minister_jacek_czaputowicz_o priorytetach_polskie_dyplomacji_w_2018_roku (accessed: 25.04.2018).

Minister Witold Waszczykowski o priorytetach polskiej dyplomacji w 2017 roku http://www.msz.gov.pl/pl/p/msz pl/aktualnosci/minister_witold_waszczykow ski_o_priorytetach_polskiej_dyplomacji_w_2017_roku (accessed: 10.02.2017).

Moczulski L.: Geopolityka. Potęga w czasie i przestrzeni. Warszawa 1999.

Molo B.: Polska wobec polityki energetyczno-klimatycznej UE $w$ drugiej dekadzie XXI w. "Krakowskie Studia Międzynarodowe" 2013, nr 4 (X).

Morgenthau H.: Polityka między narodami. Walka o potęge i pokój. Przeł. R. WŁoch. Warszawa 2010.

Mróz M.: Między Polska piastowska a jagiellońską. Kontrowersje wokół kierunków polskiej polityki zagranicznej po akcesji do Unii Europejskiej. "Dyplomacja i Bezpieczeństwo" 2013, nr 1.

Nie jesteśmy eurosceptyczni. Rozmowa z Witoldem Waszczykowskim. "Rzeczpospolita", 3 November 2015.

Niemcy na drodze do Mitteleuropy. Dyskusja. "Polityka Polska" 2016, nr 7—8. 
Nye J.S.: Soft Power. Jak osiagnać sukces w polityce światowej. Przeł. J. ZABorowsKi. Warszawa 2007.

OrŁowski T.: Geopolityka polska. W: C. JeAn: Geopolityka. Przeł. T. OrŁowski. Wrocław 2003.

Pamięć i polityka historyczna $w$ stosunkach polsko-rosyjskich. Red. S. BIELEŃ, A. SKrzyPeK. Warszawa 2017.

PflüGer E.: Warunek pojednania Polski z Rosja. "Dialog” 1998, nr 2.

Pierwszy atak będzie w cyberprzestrzeni. Rozmowa z gen. Mieczysławem Bieńkiem. "Przegląd", 20-26 October 2014.

Polacy o bezpieczeństwie narodowym $i$ NATO Komunikat $z$ badań CBOS. Oprac. K. KowALCZYK. Warszawa 2014, nr 48 - www.cbos.pl/SPISKOM. POL/2014K_048PDF (accessed: 10.08.2014).

Polityka wschodnia Polski - między fatalizmem geopolitycznym a klątwa niemocy. Red. S. Bieleń. Pułtusk-Warszawa 2019.

Polska 2013. Raport o stanie handlu zagranicznego. Polish Ministry of Economy. Warszawa 2013.

Polska - Niemcy: dobre sasiedztwo i przyjazna wspótpraca. Red. J. BARCz, M. Tomala. Warszawa 1992.

Polska - Niemcy. Partnerstwo dla Europy? Interesy, opinie elit, perspektywy. Red. P. Buras. Warszawa 2013.

Potulski J.: Wprowadzenie do geopolityki. Gdańsk 2010.

Program Prawa $i$ Sprawiedliwości 2014 - www.pis.org.pl/dokumenty?page=1 (accessed: 12.10.2015).

ProniŃSKA K.: Strategie bezpieczeństwa energetycznego państwa na przykładzie wybranych krajów UE. W: Państwo $w$ teorii $i$ praktyce stosunków międzynarodowych. Red. M. SuŁEK, J. Symonides. Warszawa 2009.

Presentation of the Action Plan for the Council of Ministers by Prime Minister Donald Tusk with a Motion for a Vote of Confidence, 23 November 2007 www.rp.pl/artykul71439.html?p=33 (accessed: 11.11.2014).

RabiJ M.: Rosyjski kapitał w Polsce? Prawie nieobecny — biznes.newsweek.pl/ rosyjskie-inwestycje-w-polsce-newsweek-pl,artykuly,285428,1,html (accessed: 20.05.014).

RotFeld A.D.: W poszukiwaniu strategii. Olszanica 2018.

Sienkiewicz M.: Koncepcja Trójmorza w polityce zagranicznej Polski po 2015 r. "Dyplomacja i Bezpieczeństwo" 2016, nr 1.

Sikorski R.: Schylek Unii nie jest przesadzony. "Gazeta Wyborcza”, 30 November 2011.

SkrzyPEK A.: Geopolityka "Międzymorza" i jej wplyw na stosunki Polski z Rosją. W: Geopolityka w stosunkach polsko-rosyjskich. Red. S. BIELEŃ, A. SKRZYPEK. Warszawa 2012.

Smolar A.: Kłopoty wymusza integrację. Rozmowa z A. Smolarem. "Tygodnik Powszechny" 2016, nr 1-2.

Sondaż FES. Niemcy widza zagrożenie w USA, Polacy - w Rosji - https://wiadomo sci.wp.pl/sondaz-fes-niemcy-widza-zagrozenie-w-usa-polacy-w-rosji (accessed: 17.02.2019). 
STAŚKIEWICZ R., WALCZAK M.: Ocena sytuacji w handlu zagranicznym z 2018 roku. Division of Macroeconomic Analyses and Forecasts in the Department of Economic Analyses. Ministry of Entrepreneurship and Technology - $D A G_{-}$ Ocena_sytuacji_w_handlu_zagranicznym_2018.pdf-Adobe Acrobat Reader DC. (accessed: 21.11.2019).

Steinmeier gegen Nato-Mitgliedchaft der Ukraine - www.spiegel.de/politik/deutschland/ukraine-krise-steinmeier-gegen-nato-mitgliedchaft-der-ukraine-a-100 04525.html (accessed: 24.11.2014).

STEMPLOWSKI R.: Wprowadzenie do analizy polityki zagranicznej RP. Wyd. II. T. 1. Warszawa 2007.

StolarczyK M.: Bezpieczeństwo Niemiec w kontekście konfliktu na wschodzie Ukrainy. "Bezpieczeństwo. Teoria i Praktyka" 2017, nr 1.

StolarczyK M.: Dylematy polityki niemieckiej Polski zwiazane z zakresem wptywu obciązeń historycznych na międzypaństwowe stosunki polsko-niemieckie. W: Bezpieczeństwo międzynarodowe Polska — Europa — Świat. Księga Jubileuszowa dedykowana Profesorowi Ryszardowi Ziębie z okazji czterdziestolecia pracy naukowej. Red. J. ZająC, A. WŁodKowsKa-BAgAn, M. KaCZMARSKI. Warszawa 2015.

StOlARCZyK M.: Kryzys uznanego (powszechnie akceptowanego) przywództwa Niemiec $w$ Unii Europejskiej. W: Kryzysy w Unii Europejskiej $w$ drugiej dekadzie XXI wieku. Uwarunkowania - przebieg — implikacje. Red. T. KuBIN, M. StolarczyK. Katowice 2018.

Stolarczyk M.: Możliwości współdziałania Polski i Niemiec w zakresie ich polityki wobec Rosji i Ukrainy. "Krakowskie Studia Międzynarodowe" 2016, nr 2.

Stolarczyк M.: Polska i Niemcy wobec kryzysu i konfliktu ukraińskiego. W: Implikacje konfliktu ukraińskiego dla polityki zagranicznej i bezpieczeństwa Polski. Aspekty polityczne, wojskowe, gospodarcze oraz społeczne. Red. K. CzORNIK, M. LaKomy, M. StolarczyK. Katowice 2015.

Stolarczyk M.: Polska i Niemcy wobec polityki wschodniej Unii Europejskiej i stosunków z Rosja w pierwszej dekadzie XXI wieku. "Rocznik Integracji Europejskiej” 2010, nr 4.

Stolarczyk M.: Prawicowy populizm w Polsce jako jedna z barier na drodze do poprawy stosunków polsko-rosyjskich. "Krakowskie Studia Międzynarodowe" 2011, nr 4.

Stolarczyk M.: Rosja w polityce Polski i Niemiec na przełomie pierwszej i drugiej dekady XXI wieku. Zakres zbieżności i różnicy stanowisk. "Studia Politicae Universitatis Silesiensis" 2014, T. 12.

StolarCZyK M.: Rosja w polityce zagranicznej Polski w latach 1992-2015. Katowice 2016.

Stolarczyk M.: Stanowisko Polski wobec kryzysu migracyjno-uchodźczego Unii Europejskiej. "Krakowskie Studia Międzynarodowe” 2017, nr 2 (XIV).

STOLARCZYK M.: Wokól formuły “polsko-niemiecka wspólnota interesów”. "Przegląd Zachodni” 1998, nr 1.

StOlARCZYK M.: Wzrost mocarstwowej pozycji Niemiec $w$ drugiej dekadzie XXI wieku. W: Między idea, pasja a działaniem. Księga jubileuszowa dedykowana 
dr. hab. Marianowi Mitrędze. Red. P. Grzywna, J. Lustig, N. StęPień-Lampa, B. ZASĘPA. Katowice 2017.

STOLARCZYK M.: Zbieżność i różnice interesów w stosunkach polsko-niemieckich $w$ latach 1989-2009. Katowice 2010.

The National Security Strategy of the Republic of Poland. Warsaw 2014 - www. mon.gov.pl (accessed: 29.11.2014).

SuŁEK M.: Dynamika zmian parametrów potegi państw regionu Azji i Pacyfiku 1985-2015. W: Region Azji i Pacyfiku w latach 1985-2015. Ciagłość $i$ zmiana $w$ regionalnym systemie międzynarodowym. Red. A. JARCZEWSKA, J. ZAJĄCZKOWSKI. Warszawa 2016.

SyKulSKi L.: Geopolityka. Skrypt dla początkujących. Częstochowa 2014.

Szabo S.F.: Na rozstajach dróg. Kryzys w stosunkach niemiecko-amerykańskich. Przeł. K. Korkosz. Warszawa 2006.

SzUBART K.: Biała Księga 2016 - niemiecka odpowiedź na obecne wyzwania w zakresie bezpieczeństwa. "Biuletyn Instytutu Zachodniego", nr 266, 16 August 2016.

SzUbART K.: Stanowisko Niemiec na szczyt NATO w Warszawie: dialog i odstraszanie. "Biuletyn Instytutu Zachodniego" 2016, nr 248.

Szubart K.: Szczyt NATO w Warszawie - konsekwencje dla Niemiec. "Biuletyn Instytutu Zachodniego" 2016, nr 260.

Śliwiński A.: Non possumus! "Polityka Polska" 2015, nr. 1.

Talaga A.: Chłód na linii USA-Rosja szansą dla Polski. "Rzeczpospolita", 17-18 August 2013.

Talaga A.: Dmuchać na Niemcy. "Rzeczpospolita", 23 December 2015.

TAlaga A.: Lepiej z Banderq niż z Moskwa. "Rzeczpospolita", 23 August 2017.

Talaga A.: Reset z Rosja to duże zagrożenie. "Rzeczpospolita", 30-31 May 2018.

Talaga A.: Wieczny konflikt z Rosja. "Rzeczpospolita", 9 May 2018.

Teczki Giedroycia. Oprac. I. Hofman, L. Unger. Lublin 2010.

Walicki A.: O Rosji inaczej. Warszawa 2019.

Warzecha Ł.: Satelita Niemiec. "Rzeczpospolita", 3 April 2012.

WŁodkowska-Bagan A.: Kultura strategiczna Polski. W: Polityka zagraniczna Polski $w$ zmieniajacym się tadzie międzynarodowym. Wybrane problemy. Red. R. ZiĘBA, T. PAwŁuszKo. Toruń 2016.

Wolff-PowęSKa A.: Doktryna geopolityki w Niemczech. Poznań 1979.

Wschodni filar. Rozmowa ze Zbigniewem Brzezińskim. "Polityka" 1999, nr 11.

Wstęp. W: Geopolityka w stosunkach polsko-rosyjskich. Red. S. BIELEŃ, A. SKRZYPEK. Warszawa 2012.

www.mapa.kuke.com.pl/ukraina.html (accessed: 4.10.2018).

ZAJĄC J.: Poland's Security Policy: The West, Russia, and the Changing International Order. London 2016.

Zbrodnie byty symetryczne. "Rzeczpospolita", 14 July 2016.

Zielonych ludzików w Polsce nie będzie. Wywiad z ambasadorem Rosji w Polsce, Siergiejem Andriejewem. "Rzeczpospolita", 26 November 2015.

ZIĘBA R.: Polityka zagraniczna Polski w strefie euroatlantyckiej. Warszawa 2013. 
ZIĘBA R.: Uwarunkowania polityki zagranicznej. W: Wstęp do polityki zagranicznej państwa. Red. R. Zį̨BA. Toruń 2004.

Żeby Polska nie przegapiła szansy na dialog z Rosja - n ld,1548975,nPack,3 http://fakty.interia.pl/tylko-u-nas/news-prof-stanislaw-bielen-zeby-polska-nieprzegapila-szansy-na-d, (accessed: 10.11.2014).

ŻuRAWSKI Vel GraJEWSKI P.: Polska wobec przywództwa Niemiec w Unii Europejskiej. "Przegląd Zachodni" 2014, nr 1.

ŻURAWSKI Vel GraJeWsKi P.: Geopolityka - siła - wola. Rzeczypospolitej zmagania z losem. Kraków 2010.

Mieczysław Stolarczyk, prof. dr hab., an academic in the Institute of Political Science and Journalism (University of Silesia, Katowice). He has written four monographs and approx. 140 papers published in academic journals and joint publications. His research interests concern first and foremost the theory of international relations, the foreign policy of FRG and Polish-German relations, the foreign policy of Russia and Polish-Russian relations in the post-Cold War period, the political aspects of European integration as well as the evolution of the global and European international system in the post-Cold War period. 